\title{
An evidence mapping of systematic reviews and meta-analysis on traditional Chinese medicine for ulcerative colitis
}

\author{
Yu-Xin Sun ${ }^{1}$, Xiao Wang ${ }^{1}$, Xing Liao², Jing Guo ${ }^{3}$, Wen-Bin Hou' ${ }^{1}$ Xin Wang ${ }^{4}$, Jian-Ping Liu ${ }^{1}$ and Zhao-Lan Liu ${ }^{1 *}$ (D)
}

\begin{abstract}
Background: Traditional Chinese Medicine (TCM) has been a proposed treatment option for ulcerative colitis (UC), however it has been difficult to understand the breadth and depth of evidence as various Chinese medicine therapies may produce effects differently. The aim of this evidence mapping is to visually understand the available evidence in the use of TCM in the treatment of UC, and to identify gaps in evidence to inform priorities of future research.

Methods: A systematic electronic literature search of six databases were performed to identify systematic reviews (SRs) on different Chinese medicine therapies in the treatment in UC. Methodological quality of the included SRs was assessed using AMSTAR 2.

Results: The mapping was based on 73 SRs, which included nine interventions that met eligibility criteria. The quality of the included SRs was very low. The diseases stages of patients with UC varied greatly, from active to remission, to non-acute outbreak, to not reported. The results mostly favored the method of intervention. Oral administration combined with enema was the most widely used route of administration in secondary research.

Conclusion: Based on the current evidence, the treatment of UC with TCM can only be recommended cautiously. A majority of included SRs did not report the location of the disease, the disease classification, and the route of administration of the intervention. Further research is needed on the effectiveness of Chinese medicine alone in the treatment of UC. The effectiveness of combined Chinese and conventional medicine combined with different routes of administration cannot be confirmed. Attention should be paid to the methodological quality of the systematic review. Unifies the outcome indicators used in the evaluation of effectiveness.
\end{abstract}

Keywords: Evidence-based medicine, Mapping review, AMSTAR 2, Herbal, Digestion

\section{Background}

Ulcerative colitis (UC) is a type of inflammatory bowel disease (IBD) caused by a variety of factors. $\mathrm{UC}$ has a tendency of recurrence throughout life [1, 2]. Crohn's disease (CD) and UC are the main disease types [3]. In 1875, Wilks and Moxon established the

\footnotetext{
*Correspondence: Izl1019@163.com

This effort provides only a broad overview of the existing evidence base. ${ }^{1}$ Center for Evidence-Based Chinese Medicine, Beijing University of Chinese Medicine, Beijing 100029, China

Full list of author information is available at the end of the article
}

term UC into the medical vernacular $[4,5]$. The main clinical manifestations of this condition are recurrent diarrhea, mucus bloody stool, and abdominal pain [6]. The primary purpose of UC treatment is to control the acute onset of the disease, heal the mucosa, maintain remission, reduce recurrence, and prevent complications [7].

Several studies have reported that UC appeared initially in urban areas, where its incidence rose rapidly before decreasing slowly [8]. The crude annual overall

(c) The Author(s). 2021 Open Access This article is licensed under a Creative Commons Attribution 4.0 International License, which permits use, sharing, adaptation, distribution and reproduction in any medium or format, as long as you give appropriate credit to the original author(s) and the source, provide a link to the Creative Commons licence, and indicate if changes were made. The images or other third party material in this article are included in the article's Creative Commons licence, unless indicated otherwise in a credit line to the material. If material is not included in the article's Creative Commons licence and your intended use is not permitted by statutory regulation or exceeds the permitted use, you will need to obtain permission directly from the copyright holder. To view a copy of this licence, visit http://creativecommons.org/licenses/by/4.0/. The Creative Commons Public Domain Dedication waiver (http://creativecommons.org/publicdomain/zero/1.0/) applies to the data made available in this article, unless otherwise stated in a credit line to the data. 
incidence for IBD per 100,000 individuals in 20112012 was 1.37 in Asia. China have high disease incidence according to an inception cohort study [9]. The incidence of IBD in China has risen by threefold in the past decade. UC is the predominant IBD in Asia [10].

This evidence mapping is largely driven by the execution of SRs and meta-analysis. In recent years, evidence-based studies of TCM in the treatment of $\mathrm{UC}$ are continuing to increase. At present, there are two overviews of SRs $[11,12]$ about the treatment of UC with TCM. One focuses on treatment with retention-enema of Chinese herbal medicine, and the other uses an overview method to summarize the evidence. Our study is not limited to the route of administration in treatment; rather our focus is on the distribution of evidence. There is value in evaluating research conducted in terms of quality and interventions used to help evaluate progress made to date as well as determine future directions in research. We used evidence mapping to visualize the results, where the systematic review mapping can map out and categorize existing literature on a particular topic in order to identify gaps in research literature from which to commission further reviews and/or primary research [13].

Mapping review is used to present evidence in a field using a visual graph or chart after systematic researched. These maps provide assessments of knowledge gaps, knowledge gluts, and patterns across the research literature that promote best practice and direct research resources towards the highest quality research [14]. It can provide a broad and often comprehensive summation of a topic area and, as such, have value for those coming to a subject for the first time. However, as it is difficult to obtain a complete overview of a research topic for a single original study or a systematic review, we chose to conduct a mapping review of SRs. To provide the depth and width of current evidence on various interventions, we conducted an overview of relevant systematic reviews that have been published to date. Therefore, the objective of this study was to identify, describe and organize the current available evidence about TCM on the treatment of UC.

\section{Methods}

\section{Criteria for considering reviews for inclusion}

A comprehensive search of databases PubMed, Cochrane Library, CNKI, WanFang, VIP, and SinoMed, was conducted for systematic reviews published from database inception up to and including March 16, 2021. Search terms included "ulcerative colitis", "Chinese herbal medicine", "plant", "systematic review" and "meta".

Search strategy used in PubMed database:

\#1 Search (((ulcerative colitis[MeSH Terms]) OR ulcerative colitis[Title/Abstract]) OR ulcerative colitis[Text Word]) OR ulcerative colitis[Other Term].

\#2 Search ()(()((((Traditional Chinese Medicine[Title) Abstract]) OR Traditional Medicine, Chinese[Title/Abstract]) OR Chinese Traditional Medicine[Title/Abstract]) OR Chinese Medicine, Traditional[Title/ Abstract]) OR Phytotherapy[Title/Abstract]) OR Medicine, traditional[Title/Abstract]) OR Medicine, Chinese Traditional[Title/Abstract]) OR Plants, Medicinal[Title/ Abstract]) OR Herbal Medicine[Title/Abstract]) OR Plant Preparations[Title/Abstract]) OR Drugs, chinese herbal[Title/Abstract].

\#3 Search ((review[Title/Abstract]) OR systematic review[Title/Abstract]) OR meta[Title/Abstract].

\#4 \#1 AND \#2 AND \#3.

Type of study

We included systematic reviews with or without metaanalysis.

\section{Participants}

Patients with a confirmed diagnosis of UC, regardless of disease duration and severity, were included.

\section{Interventions}

We included SRs where TCM interventions were used, including Chinese herbal medicine, extracts from herb mixtures, individual herbs, Chinese patent medicine, or herb compounds prescribed by Chinese medicine practitioners, regardless of the potential mechanisms of action. Eligible treatments allowed the intervention to be combined with conventional medicine or placebo. No limitation on drug dosage form and route of administration.

\section{Outcome measures}

Systematic reviews were considered where outcome measures included clinical effectiveness, TCM syndromes, inflammatory levels, immunological indicators, blood indicators, electronic endoscopy results, intestinal flora, clinical symptom and incidence of adverse reactions.

\section{Exclusion criteria}

Studies that involved comorbidity, in particular intestinal diseases, such as $\mathrm{CD}$, schistosomiasis, bacillary dysentery, and intestinal tuberculosis, were excluded. Interventions involving herbal medicines not prescribed according to TCM theory or by Chinese medicine practitioners, were also excluded. 


\section{Data extraction and methodological quality}

Microsoft Excel was used for data extraction and bubble plot creation. Two researchers independently screened the studies, extracted the data, and evaluated the report. A third author was consulted if there were discrepancies. Relevant data extracted included author(s), year of publication, country of origin (based on primary author's affiliation), total number of patients, diagnostic criteria, severity of illness, medication in intervention group and control group, outcomes, safety evaluation, quality assessment tools, and funding support. We used AMSTAR 2 [15] (a measurement tool to assess systematic reviews 2) as a quality assessment tool, and two experts assessed each study. If there were any discrepancies between the two reviewers, a third reviewer was consulted.

AMSTAR 2 was used to critically appraise the methodological quality of the SRs. AMSTAR 2 contains 16 items that appraise critical flow and bias using ratings of "yes", "partial yes" or "no". Using this rating system, the overall confidence for the SRs were assessed as "high" (no or non-critical weakness in all items), "moderate" (more than one non-critical weakness among all the items), "low" (one critical flaw with or without non-critical weakness), or "critically low" (more than one critical flaw with or without non-critical weakness) [15].

\section{Graphical visualization of results}

Findings for included SRs were summarized in:

(a) tables describing the characteristics and outcomes of the included SRs;

(b) graphical display of the results of literature quality evaluation, with mapping based on bubble plots. Display information includes: (1) effectiveness trend as 'no difference', 'potentially effective', and 'effective' in $x$-axis. (2) estimated size of the literature $y$-axis; and (3) the bubble size as per AMSTAR 2 assessment, representing Chinese herbal therapy intervention type.

\section{Results}

Overall assessment of included systematic reviews Our search identified 1892 potential systematic reviews (Fig. 1). After removing duplicate publications,

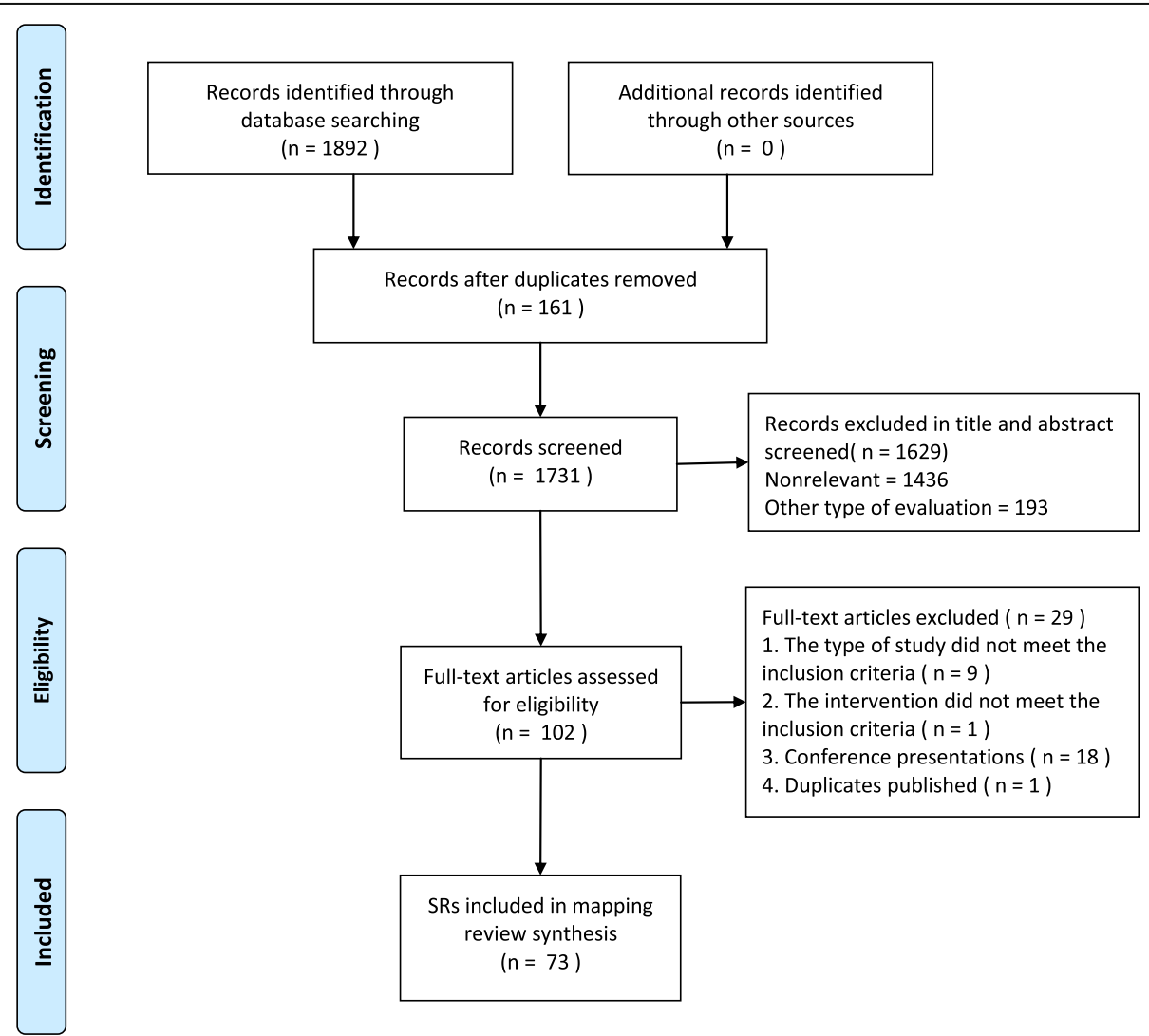

Fig. 1 Flow diagram of literature searches 
the titles and abstracts of 1731 reviews were screened for relevancy. Of these, the full-text articles of 102 reviews were reviewed for eligibility. Finally, 73 SRs were included in our final review (Fig. 1) [16-88]. The basic characteristics of the included SRs are shown in Table 2 in Appendix 1. Among the included studies, one systematic review reported participants in the active phase of UC [16], one reported participants in remission [17], whilst another reported participants that were in a non-acute occurrence of UC [18]. 10 SRs did not limit the severity of the disease [19-28], whilst other reviews did not report severity of UC. In most studies, the control group included the first-line medication of conventional medicine, such as mesalamines, amino preparations, hormone preparations, and probiotics, whilst some studies used other herbal medicines and placebo. The administration routes of the intervention groups included oral administration, enema, embolization, injection, ultrasound induction and acupoint application.

\section{Literature publication}

Figure 2 shows the number of included SRs of TCM in the treatment of UC by published year. Most of the 73 included SRs were published in the last 8 years, with the majority in 2012. The number of published SRs each year has increased from 0 to 1 from 2006 to 2011. Interestingly, the number of SRs published each year has significantly increased over the last decade. Results for 2021 are not complete, and reflect SRs published up to 16 March 2021.

\section{Quality of included systematic reviews}

AMSTAR 2 was used to critically appraise the reporting quality of each included systematic review and all reviews were found to be of critically low quality (Fig. 3). Whilst majority of reviews assessed the risk of bias in interpreting results and reported any conflicts of interest, we found that no reviews mentioned study lists and reported exclusion criteria in the review methods.

\section{Outcomes}

Outcome indicators (listed in Table 3 in Appendix 2) included clinical effectiveness, incidence of adverse reactions, TCM syndromes score, levels of inflammatory factors, immunological indicators, blood indicators, results of electronic endoscopy, intestinal flora, and description of clinical symptoms. A total of 44 outcomes were identified as having inconsistent reporting and measurements. Continuous variables were presented as mean with/without standard deviation, and dichotomous variables were described as a number or percentage. We summarized all the reported outcomes and presented the results with descriptive statistics (Table 1). Commonly reported outcomes included clinical effects $(71 / 73,97.3 \%)$, adverse reaction rate $(42 / 73,57.5 \%)$, clinical symptoms (19/73, $26.0 \%)$, serum inflammatory cytokines levels (9/73,

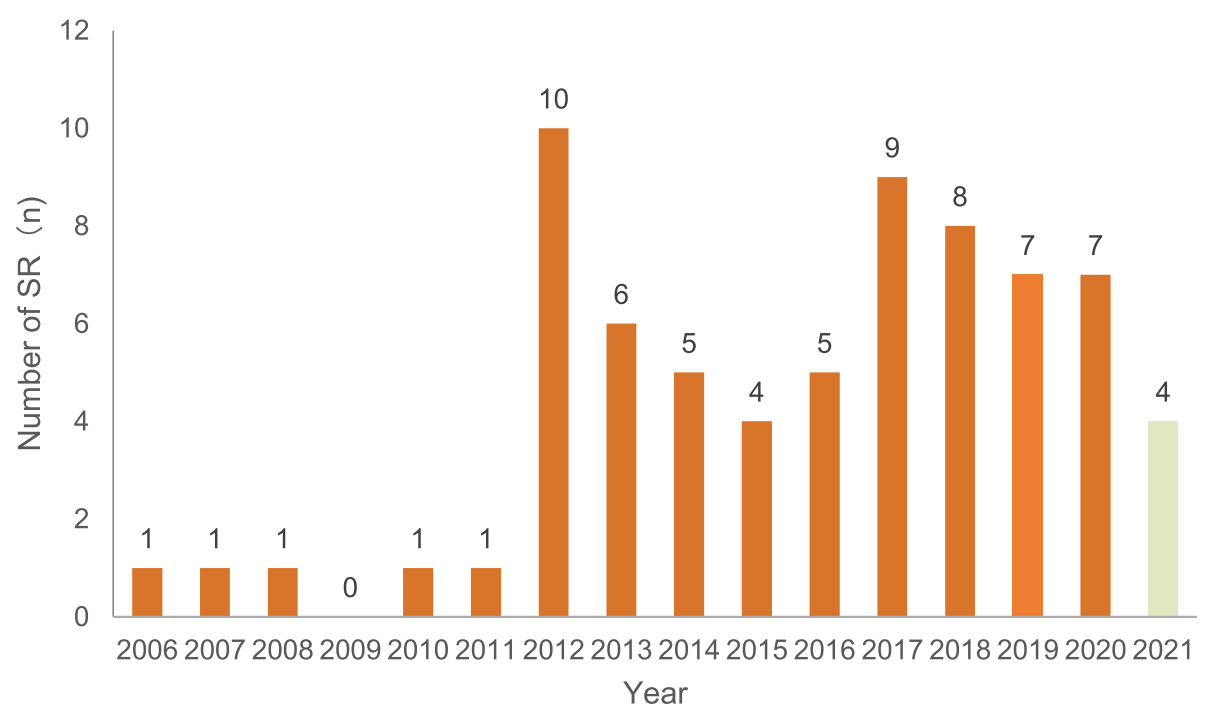

Fig. 2 Systematic reviews of TCM in the treatment of UC published to 2021 


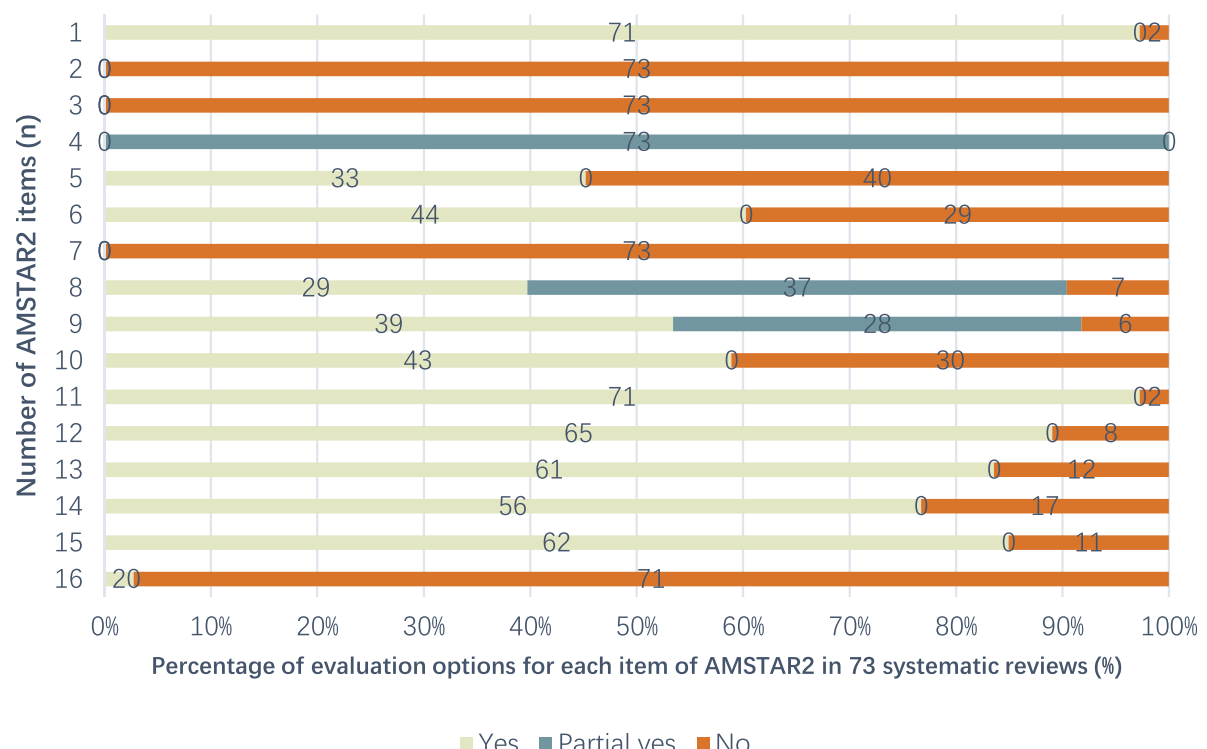

Fig. 3 Methodological quality of systematic reviews with meta-analysis of TCM in the treatment of UC Measured with AMSTAR 2 tool

$12.3 \%)$, infection screening $(8 / 73,11.0)$, performance of colonoscopy $(24 / 73,32.9 \%)$, immune factor level $(4 /$ $73,5.5 \%)$, blood routine $(4 / 73,5.5 \%)$, and level of intestinal flora $(1 / 73,1.4 \%)$.

Outcome indicators were further classified. Clinical effects included clinical effectiveness, total effectiveness, cure rate, significant effectiveness, inefficiency rate and recurrence rate. Clinical symptoms included details such as TCM syndrome, total symptom score before and after treatment, disappearance of mucopurulent bloody stool/abdominal pain/diarrhea/tenesmus, DAI and Geboes index. Serum inflammatory cytokines levels included IgA/M/G. Immune factor levels included TNF-a and IL-6/8/10/13/17/23. Infection screening included ESR and CRP. Compared with conventional medicine, 68 SRs reported positive outcomes. Two SRs reported no difference in clinical efficacy compared with conventional medicine $[29,30]$. One review reported no difference in ESR compared with conventional medicine [31]. Intervention measures in 34 SRs included only TCM treatment, whilst the remaining integrated both traditional Chinese and conventional medicine in treatment. 37 SRs reported safety outcomes of which the majority were positive, and 9 reported a negative incidence of adverse reaction rate $[19,20$, $24,25,30,32-35]$. Safety outcomes were not reported in 25 SRs [22, 23, 28, 36-57]. Publication bias was not investigated in 11 reviews $[18,22,29$,
$30,41,47,54,58-61]$. There were $30 \mathrm{SRs}$ that did not report funding support $[16,17,19,22,24,27$, $36-38,40,41,43-46,48,49,54-56,59,62-70]$, and 14 of them were dissertations [16, 17, 22, 37, $40,45,49,60,62,63,65,68-70]$.

\section{Evidence Mapping}

Evidence mapping focused on clinical effectiveness outcomes. We evaluated the effectiveness, literature size and confidence level for each intervention identified in the SRs. The most common treatment in randomized controlled trials in the SRs were oral administration and enema interventions with Chinese and conventional medicine $(n=18)$ [19-21, $27,34,40,46,53,66-68,70-76] .12$ studies involved TCM retention enema treatments only $(n=$ 12) $[30,32,41-44,48,55,64,77-79]$ and another 12 studies included both oral administration and enema with TCM $(\mathrm{n}=12)[17,18,28,31,57,62$, $63,65,69,80-82] .16$ reviews did not report specific routes of administration in the intervention group [22-24, 38, 47, 50-52, 54, 58-60, 83-86]. The use of TCM treatment in UC is positive but the quality of SRs are low. The evidence mapping showed that there is limited number of studies using between TCM and conventional medicine combined with multiple routes of administration is inconclusive, indicating a need for more original research in this area (Fig. 4). 
Table 1 Outcomes reported in 73 reviews evaluating TCM in the treatment of UC

\begin{tabular}{|c|c|c|c|}
\hline & & Outcomes & $\begin{array}{l}\text { Number of } \\
\text { reviews (\%) }\end{array}$ \\
\hline \multirow[t]{6}{*}{ Clinical effects } & 1 & Clinical effectiveness & $28(38.4)$ \\
\hline & 2 & Total effectiveness & $48(65.8)$ \\
\hline & 3 & Cure rate & $12(16.4)$ \\
\hline & 4 & Significant effectiveness & $2(2.7)$ \\
\hline & 5 & Inefficiency rate & $2(2.7)$ \\
\hline & 6 & Recurrence rate & $23(31.5)$ \\
\hline Adverse reaction & 7 & Adverse reaction rate & $42(57.5)$ \\
\hline \multirow{7}{*}{$\begin{array}{l}\text { Immune factor } \\
\text { levels }\end{array}$} & 8 & TNF-a & $5(6.8)$ \\
\hline & 9 & IL-6 & $5(6.8)$ \\
\hline & 10 & IL-8 & $3(4.1)$ \\
\hline & 11 & IL-10 & $1(1.4)$ \\
\hline & 12 & IL-13 & $1(1.4)$ \\
\hline & 13 & IL-17 & $3(4.1)$ \\
\hline & 14 & IL-23 & $3(4.1)$ \\
\hline \multirow{2}{*}{$\begin{array}{l}\text { Infection } \\
\text { screening }\end{array}$} & 15 & CRP & 7 (9.6) \\
\hline & 16 & ESR & $5(6.8)$ \\
\hline \multirow{3}{*}{$\begin{array}{l}\text { Performance of } \\
\text { colonoscopy }\end{array}$} & 17 & Performance of colonoscopy & $20(27.4)$ \\
\hline & 18 & Mucosal biopsy score & $4(5.5)$ \\
\hline & 19 & Efficacy of mucosal lesions & $1(1.4)$ \\
\hline \multirow[t]{15}{*}{ Clinical symptoms } & 20 & TCM syndrome score & $14(19.2)$ \\
\hline & 21 & DAl & $9(12.3)$ \\
\hline & 22 & Abdominal pain & $6(8.2)$ \\
\hline & 23 & Diarrhea & $6(8.2)$ \\
\hline & 24 & Pus and blood stool & $6(8.2)$ \\
\hline & 25 & Tenesmus & $3(4.1)$ \\
\hline & 26 & Time of bellyache disappearance & $3(4.1)$ \\
\hline & 27 & Time of diarrhea disappearance & $3(4.1)$ \\
\hline & 28 & $\begin{array}{l}\text { Time of hematochezia } \\
\text { disappearance }\end{array}$ & $2(2.7)$ \\
\hline & 29 & Time of fever disappearance & $2(2.7)$ \\
\hline & 30 & Defecate occult blood & $2(2.7)$ \\
\hline & 31 & $\begin{array}{l}\text { Total symptom score before and } \\
\text { after treatment }\end{array}$ & $1(1.4)$ \\
\hline & 32 & Geboes index & $1(1.4)$ \\
\hline & 33 & Symptom relief time & $1(1.4)$ \\
\hline & 34 & Intervention treatment & $1(1.4)$ \\
\hline \multirow{3}{*}{$\begin{array}{l}\text { Serum } \\
\text { inflammatory } \\
\text { cytokines levels }\end{array}$} & 35 & $\lg G$ & $4(5.5)$ \\
\hline & 36 & $\lg A$ & $3(4.1)$ \\
\hline & 37 & $\lg M$ & $2(2.7)$ \\
\hline \multirow[t]{3}{*}{ Blood routine } & 38 & $\begin{array}{l}\text { Negative conversion rate of White } \\
\text { blood cells and red blood cells in } \\
\text { stool routine }\end{array}$ & $1(1.4)$ \\
\hline & 39 & Whole blood viscosity score & $1(1.4)$ \\
\hline & 40 & Plasma viscosity & $1(1.4)$ \\
\hline
\end{tabular}

Table 1 Outcomes reported in 73 reviews evaluating TCM in the treatment of UC (Continued)

\begin{tabular}{llll}
\hline & & Outcomes & $\begin{array}{l}\text { Number of } \\
\text { reviews (\%) }\end{array}$ \\
\hline $\begin{array}{l}\text { Level of intestinal } \\
\text { flora }\end{array}$ & 41 & Bifidobacterium level & $1(1.4)$ \\
& 42 & Lactobacillus level & $1(1.4)$ \\
& 43 & Enterococcus level & $1(1.4)$ \\
& 44 & E. coli level & $1(1.4)$
\end{tabular}

Abbreviations: DAI DNA-dependent activator of IFN-regulatory factors; IL inflammatory factors levels of interleukin; ESR erythrocyte sedimentation rate; CRP C-reaction protein; IgA immunoglobulin $\mathrm{A}$; IgM immunoglobulin $\mathrm{M}$; $\lg G$ immunoglobulin $\mathrm{G}$

\section{Discussion}

There is a constant demand for health care when it comes to chronic disease. Patients with UC tend to have long term effects with increased risk of cancer, which may develop into UC-related colorectal cancer (UC-CRC). UC-CRC is one of the most serious complications in patients with long-term UC [89]. Among all cancers, colorectal cancer is a high-cost, high-burden malignancy that takes a heavy toll on health care systems and patients [90-92]. Evidence mapping of SRs in TCM is therefore critical to understand where further research should be focused to ensure the financial and health toll on patients with UC.

\section{Main findings}

In accessing the clinical effectiveness of treatment options for UC in the published SRs, we found that a majority of clinical trials used TCM as intervention through a variety of routes of administrations. Our evidence mapping showed that oral administration and enema with both Chinese and conventional medicine was most widely studied $(n=18)$. Oral combined enema was the most widely used route of administration in the trials. TCM only was the most common intervention $(n=34)$, followed by the combination of TCM and conventional medicine $(n=23)$. The overall confidence level for each review was limited. So whilst TCM treatments may be effective in $\mathrm{UC}$, more research is needed to determine whether it can be recommended to patients.

The conclusion of this evidence mapping review however cannot provide recommendations for clinical practice due to insufficient strength of evidence and limitation of research type. AMSTAR2 was only used to evaluate the quality of methodological reports and not the efficacy of medicine. A mapping review can help in describing the research field and 
provide a basis for an informed decision about whether to undertake an in-depth review and synthesis of all or a subset of studies. However, its analysis only characterizes quantity and quality of literature rather than offering recommendations for practice and future research though the quantitative synthesis. The SR can only answer one specific PICOS clinical question at a time. We chose to include SRs as the study type in our evidence mapping as it can provide a broad and often comprehensive summation of a topic area, providing value for those coming to a subject for the first time. There are some shortcomings attributed to mapping reviews, specifically characterizing at a broad descriptive level. This can oversimplify the picture or mask considerable variation (heterogeneity) between studies and their findings, depending on the degree of specificity of the coding process [13]. The purpose of the statistics of outcomes is to sort out the outcomes and degree of concern in the past clinical trials of TCM in the treatment of UC: the greater the percentage, the more attention it is likely to receive. It provides evidence for the establishment of 'core outcome set (COS)', that is a set of minimum and consensus standardized indicators that should be measured and reported by all clinical trials in a specific health or healthcare field. However, we should consider that the choice of outcomes in clinical trials depends on the stage of UC, active or in remission, and the selection of primary and secondary outcomes.
It is noteworthy that the number of SRs on TCM in the treatment of UC has increased since 2012. Prior to this, the number of trials in 2006-2011 was $0-1$. Previously UC had a higher incidence in Western countries, but there has been a dramatic increase in the incident rate of $\mathrm{UC}$ in Asia in recent years. Because the disease is difficult to cure, easy to relapse, and the risk of cancer lesions is high, it often takes lifelong medication. There are major concerns in diagnosis and treatment of UC worldwide, with research currently being a hot topic in the field of gastroenterology.

Various guidelines for the diagnosis and treatment of UC are constantly being revised. In 2004, the American Gastroenterology Association (AGA) revised "Ulcerative colitis practice guidelines in adults" [93], British Society of Gastroenterology (BSG) reviewed "Guidelines for the management of inflammatory bowel disease in adults" [94], and 2010 World Gastroenterology Organization Practice Guidelines for the Diagnosis and Management of IBD [95]. In 2007, Chinese Society of Gastroenterology (CSGE) "the Consensus Opinions on the Diagnostic and Treatment Specifications for Inflammatory Bowel Disease in China" [96]. In 2010, after repeated discussions and practice, the "Consensus on the Diagnosis and Treatment of Integrated and conventional Medicine for Ulcerative Colitis" [97] was formed. This is the first formal consensus opinion on the treatment of UC in Chinese medicine. This may be one of the reasons why the Chinese medicine field began to pay

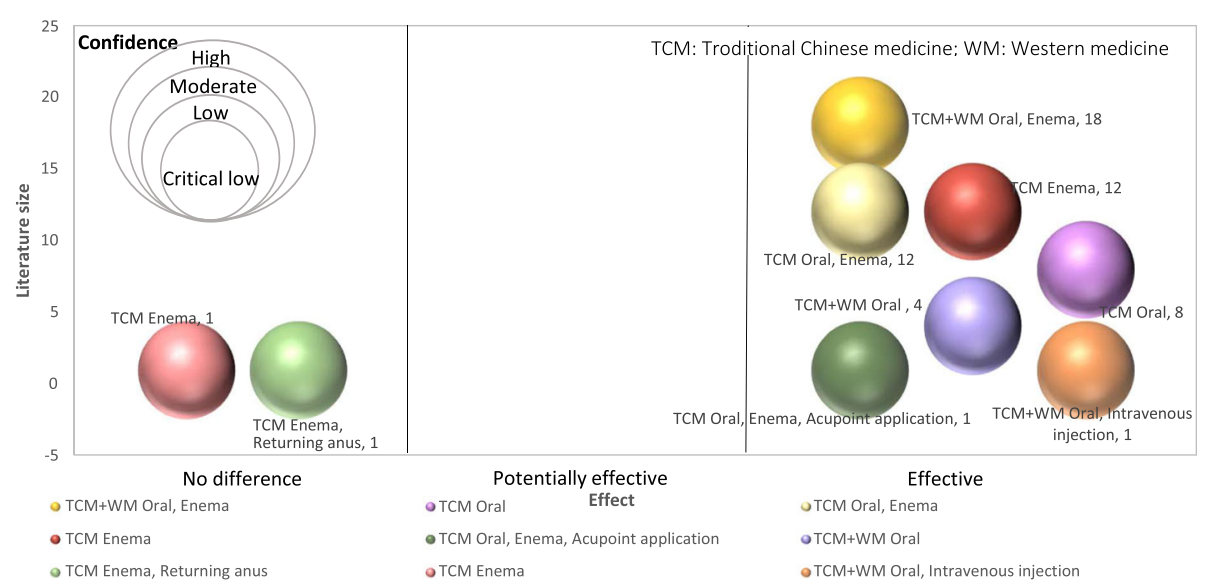

Fig. 4 Evidence map of TCM in the treatment of UC. The bubble plot in Fig. 4 summarizes TCM treatment for UC in systematic reviews published as of 2021, the estimated size of the literature (y-axis), the effectiveness trend according to reviews ( $x$-axis), and the confidence of systematic reviews (bubble size) 
attention to the disease, and the number of SRs increased from 2012.

\section{Strength and limitations \\ Strength}

The systematic evaluation of relevant topics was searched. We used the PICOS format to organize the available information and describe the results applied to more specific scenarios according to current clinical practice. Our study included 73 SRs, and it is difficult to describe the information involved by general methods. In fields where there are enormous amounts of available information, the bubble plots are a good option. Mapping methodologies describe the quality of included SRs, and we could combine the results of all conducted studies in the field. We assessed the quality of included reviews with AMSTAR 2. This approach allowed results to be displayed on a bubble plot for each systematic review with respect to the other ones with the same comparison, providing a quick view of the existing evidence and their quality.

\section{Limitations}

There were several limitations to this research. Firstly, the results of our review need to be interpreted carefully because of the many characteristics in the SRs. Current evidence for interventions used in $\mathrm{UC}$ therefore cannot be considered conclusive and show a clear need for further research. Second, our study has some methodologic limitations. When drawing the evidence map, we included domains of estimated overall clinical effectiveness ( $x$-axis), literature size (y-axis), and the confidence of the evidence (size of the bubble). When determining clinical effectiveness, we relied on the results of 58 SRs that potentially included biased information. The clinical effectiveness depends on these outcome indicators, including clinical effectiveness, total effectiveness, cure rate, significant effectiveness, inefficiency rate. Moreover, the AMSTAR 2, used to determine the confidence level, was originally developed to assess the appropriateness of reporting SRs and not to evaluate the confidence level of SRs. We acknowledge that there may be more efficient ways of drawing an evidence map.
Since only a few SRs in the included studies showed the stage of the disease, we did not evaluate characteristics on subgroups in acute and non-acute phase of UC. The main reason may be that many RCTs did not clearly define the disease stages of participants, which is a methodological demerit in this field. We hope that more RCTs with definite inclusion and exclusion criteria can be carried out to evaluate the effects on subgroups in the future.

\section{Conclusion}

In conclusion, oral administration, in combination with enema in both Chinese and conventional medicine, has been the most frequently tested intervention in TCM for UC. But on the basis of current evidence, this therapy can only be recommended cautiously. The low grade methodology quality of the included SRs in our mapping research cannot provide a high level of evidence to recommend in clinical practice. The major issue was that SRs failed to report the location of the disease, the type of the disease, and the route of administration of the intervention. Outcome indicators were also not uniformly reported, and the exact effect of Chinese medicine on UC cannot be derived from available evidence. Further evaluation of the effects of TCM is needed, either alone or in combination with conventional medicine, or via multiple administration routes. Low quality RCTs of TCM in the treatment of UC is of concern. As no valid conclusion can be drawn, it is a waste of energy of authors. Clinicians should carefully execute the trial and report details of the research process. They should also be aware that negative published data do not change the reputation of these authors, whilst do not annoying editors and readers. Before the systematic evaluation, the researchers should register the protocol and list the excluded literatures. In the future, we believe when high quality clinical studies are conducted of various Chinese herbal interventions, superior evidence will be available to confirm the results of these trials. In the meanwhile, evidence mapping is a useful and reliable methodology to identify and present the current evidence about therapeutic interventions. The results can help us accurately locate the focal point and insufficiency of current research in the field. 


\section{Appendix 1}

Table 2 Summary of the included systematic reviews

\begin{tabular}{|c|c|c|c|c|c|c|c|}
\hline No. & $\begin{array}{l}\text { Study ID } \\
\text { (first } \\
\text { author, } \\
\text { year) }\end{array}$ & Interventions & $\begin{array}{l}\text { Review objectives (quote } \\
\text { from the original paper) }\end{array}$ & Population & Intervention (TCM used) & Comparator & $\begin{array}{l}\text { Number } \\
\text { of } \\
\text { studies }\end{array}$ \\
\hline 1 & $\begin{array}{l}\text { Gong } \\
\text { Y2014 }\end{array}$ & Decoction & $\begin{array}{l}\text { To evaluate the efficacy and } \\
\text { safety of Sishen Pill in the } \\
\text { treatment of UC. }\end{array}$ & $n=839$ & Sishen Pills & $\begin{array}{l}\text { SASP, Gubenyichang } \\
\text { Tablets, Bupiyichang Pill, } \\
\text { Hydrocortisone }\end{array}$ & 10 RCTs \\
\hline 2 & $\begin{array}{l}\mathrm{Li} \\
\text { WH2013 }\end{array}$ & Decoction & $\begin{array}{l}\text { To evaluate the efficacy and } \\
\text { safety of Pulsatilla Decoction } \\
\text { for UC. }\end{array}$ & $n=1124$ & Pulsatilla Decoction & SASP & $10 \mathrm{RCTs}$ \\
\hline 3 & $\begin{array}{l}\text { Zuo } \\
\text { HB2013 }\end{array}$ & Decoction & $\begin{array}{l}\text { To evaluate the efficacy and } \\
\text { safety of Pulsatilla Decoction } \\
\text { for UC. }\end{array}$ & $n=1480$ & Pulsatilla Decoction & $\begin{array}{l}\text { SASP, 5-ASA, Hormone } \\
\text { preparation }\end{array}$ & 12 RCTs \\
\hline 4 & $\begin{array}{l}\text { Pei } \\
\text { QW2012 }\end{array}$ & Decoction & $\begin{array}{l}\text { To evaluate the effectiveness } \\
\text { and safety of Jiajian Banxia } \\
\text { Xiexin decoction forUC. }\end{array}$ & $n=736$ & $\begin{array}{l}\text { Banxia Xiexin Decoction, } \\
\text { Danggui Shaoyao Powder, } \\
\text { Taohong Siwu Decoction }\end{array}$ & $\begin{array}{l}\text { SASP, Bifico, Hormone } \\
\text { preparation, Mesalazine }\end{array}$ & 8 RCTs \\
\hline 5 & $\begin{array}{l}\text { Wen } \\
\text { Y2017 }\end{array}$ & $\begin{array}{l}\text { Decoction, } \\
\text { Chinese } \\
\text { patent } \\
\text { medicine }\end{array}$ & $\begin{array}{l}\text { To make a Meta-analysis of } \\
\text { the effectiveness and safety of } \\
\text { Shenling Baizhu Powder for } \\
\text { the treatment of UC, thus to } \\
\text { provide evidence for the clin- } \\
\text { ical treatment of UC. }\end{array}$ & $n=1498$ & Shenling Baizhu Powder & $\begin{array}{l}\text { SASP, Mesalazine, } \\
\text { Hormone preparation, } \\
\text { Osalazine }\end{array}$ & 19 RCTs \\
\hline 6 & $\begin{array}{l}\text { Chen } \\
\text { K2016 }\end{array}$ & $\begin{array}{l}\text { Chinese } \\
\text { patent } \\
\text { medicine }\end{array}$ & $\begin{array}{l}\text { Generally evaluate the } \\
\text { therapeutic effect of Shenling } \\
\text { Baizhu Powder combined } \\
\text { with Western Medcine on UC. }\end{array}$ & $n=884$ & Shenling Baizhu Powder & SASP, Mesalazine & 10 RCTs \\
\hline 7 & Lu2017 & $\begin{array}{l}\text { Chinese } \\
\text { patent } \\
\text { medicine }\end{array}$ & $\begin{array}{l}\text { To evaluate the clinical } \\
\text { efficacy and safety of Shenling } \\
\text { Baizhu powder in the } \\
\text { treatment of UC by means of } \\
\text { evidence-based medicine. }\end{array}$ & $n=1736$ & Shenling Baizhu Powder & $\begin{array}{l}\text { Mezalazine, SASP, } \\
\text { Metronidazole, Osalazina }\end{array}$ & $20 \mathrm{RCTS}$ \\
\hline 8 & $\begin{array}{l}\text { Wang } \\
\text { XY2017 }\end{array}$ & $\begin{array}{l}\text { Chinese } \\
\text { patent } \\
\text { medicine }\end{array}$ & $\begin{array}{l}\text { To evaluate the clinical } \\
\text { efficacy and safety of Shenling } \\
\text { Baizhu Powder in the } \\
\text { treatment of UC. }\end{array}$ & $n=1041$ & Shenling Baizhu Powder & SASP, Mesalazine & 12 RCTs \\
\hline 9 & $\begin{array}{l}\text { Wei } \\
\text { Y2018 }\end{array}$ & $\begin{array}{l}\text { Decoction, } \\
\text { Chinese } \\
\text { patent } \\
\text { medicine }\end{array}$ & $\begin{array}{l}\text { To evaluate the clinical } \\
\text { efficacy of retention enema } \\
\text { with TCM in the treatment of } \\
\text { UC. }\end{array}$ & $n=1447$ & $\begin{array}{l}\text { Baishao Qiwu Granule, } \\
\text { Changyankang I, Compound } \\
\text { Xuejie Enema on the Blood } \\
\text { Rheology, Colon soup, Kuijie } \\
\text { enema, Lianbei Mixture, } \\
\text { Qingjie Qushi Decoction, } \\
\text { Shibai Shenbai Decoction }\end{array}$ & $\begin{array}{l}\text { SASP, Hormones, } \\
\text { gentamicin, } \\
\text { dexamethasone, } \\
\text { furazolidone, } \\
\text { montmorillonite } \\
\text { powder,smecta }\end{array}$ & $16 \mathrm{RCTs}$ \\
\hline 10 & $\begin{array}{l}\text { Zhang } \\
\text { LH2018 }\end{array}$ & $\begin{array}{l}\text { Decoction, } \\
\text { Chinese } \\
\text { patent } \\
\text { medicine }\end{array}$ & $\begin{array}{l}\text { To evaluate Fuzilizhong } \\
\text { decoction and its modified } \\
\text { decoction systematically and } \\
\text { summarize the clinical efficacy } \\
\text { and safety of the treatment of } \\
\text { UC. }\end{array}$ & $n=688$ & $\begin{array}{l}\text { Fuzi Lizhong decoction, Sishen } \\
\text { Pill, Kangfuxin solution }\end{array}$ & SASP, Kangfuxin & 8 RCTs \\
\hline 11 & $\begin{array}{l}\text { Li } \\
\text { HB2017 }\end{array}$ & $\begin{array}{l}\text { Chinese } \\
\text { patent } \\
\text { medicine }\end{array}$ & $\begin{array}{l}\text { To systematically evaluate the } \\
\text { clinical efficacy and safety of } \\
\text { Compound Huangbo liquid } \\
\text { combined with chemical } \\
\text { medicine in the treatment of } \\
\text { UC, and to provide evidence- } \\
\text { based reference }\end{array}$ & $n=737$ & $\begin{array}{l}\text { Compound Huangbo liquid, } \\
\text { Mezalazine }\end{array}$ & $\begin{array}{l}\text { SASP, Mezalazine, 5-ASA, } \\
\text { Hormones, immunosup- } \\
\text { pressants, physiological } \\
\text { saline }\end{array}$ & 8 RCTs \\
\hline 12 & $\begin{array}{l}\mathrm{Li} \\
\mathrm{HB} 2018\end{array}$ & $\begin{array}{l}\text { Chinese } \\
\text { patent }\end{array}$ & $\begin{array}{l}\text { To systematically evaluate } \\
\text { therapeutic efficacy and safety }\end{array}$ & $n=649$ & $\begin{array}{l}\text { Compound kushen colon- } \\
\text { release capsule }\end{array}$ & SASP, Mezalazine, placebo & $9 \mathrm{RCTS}$ \\
\hline
\end{tabular}


Table 2 Summary of the included systematic reviews (Continued)

\begin{tabular}{|c|c|c|c|c|c|c|c|}
\hline No. & $\begin{array}{l}\text { Study ID } \\
\text { (first } \\
\text { author, } \\
\text { year) }\end{array}$ & Interventions & $\begin{array}{l}\text { Review objectives (quote } \\
\text { from the original paper) }\end{array}$ & Population & Intervention (TCM used) & Comparator & $\begin{array}{l}\text { Number } \\
\text { of } \\
\text { studies }\end{array}$ \\
\hline 13 & $\begin{array}{l}\text { Huang } \\
\text { FMZ2014 }\end{array}$ & Decoction & $\begin{array}{l}\text { To evaluate the efficacy of } \\
\text { JieDuXiaoYongFa and the } \\
\text { variation of relevant indicators } \\
\text { compared to conventional } \\
\text { medicine for the treatment of } \\
\text { UC. }\end{array}$ & $n=1884$ & NR & $\begin{array}{l}\text { SASP, Mezalazine, } \\
\text { Hormones, Gentamicin, } \\
\text { Penicillin, Smecta }\end{array}$ & $23 \mathrm{RCTs}$ \\
\hline 14 & $\begin{array}{l}\text { Li HB- } \\
\text { a2018 }\end{array}$ & $\begin{array}{l}\text { Chinese } \\
\text { patent } \\
\text { medicine }\end{array}$ & $\begin{array}{l}\text { To systematically evalutate the } \\
\text { clinical efficacy of Kangfuxin } \\
\text { Liquid versus aminosalicylic } \\
\text { acid in treating UC, in order to } \\
\text { provide scientific basis for } \\
\text { clinical promotion. }\end{array}$ & $n=806$ & Kangfuxin Liquid & $\begin{array}{l}\text { SASP, 5-ASA, Folic acid, } \\
\text { Metronidazole }\end{array}$ & 9 RCTs \\
\hline 15 & $\begin{array}{l}\text { Liu } \\
\text { G2011 }\end{array}$ & $\begin{array}{l}\text { Chinese } \\
\text { patent } \\
\text { medicine }\end{array}$ & $\begin{array}{l}\text { To evaluate the effect of the } \\
\text { treatment based on Kangfuxin } \\
\text { liquid in UC. }\end{array}$ & $n=607$ & Kangfuxin Liquid & NR & $8 \mathrm{RCTS}$ \\
\hline 16 & $\begin{array}{l}\text { Gu } \\
\text { SZ2018 }\end{array}$ & $\begin{array}{l}\text { Decoction, } \\
\text { Chinese } \\
\text { patent } \\
\text { medicine }\end{array}$ & $\begin{array}{l}\text { To systematically evaluate the } \\
\text { efficacy and safety of the RCT } \\
\text { of oral Chinese medicine for } \\
\text { the treatment of UC. }\end{array}$ & $n=1703$ & $\begin{array}{l}\text { Kuijie Decoction, } \\
\text { Changyankang, Jianpi } \\
\text { Yuchang Decoction, } \\
\text { Qingchang Huashi Decoction, } \\
\text { Sijunzi Decoction, Xianglian } \\
\text { Zhixie Tablet, Wenjing } \\
\text { Decoction, Juyuan Decoction, } \\
\text { Wumei Pill, Qingre Lishi } \\
\text { Recipe, Baiji Yukui Decoction, } \\
\text { Changqingshu Decoction, } \\
\text { Jianpi Huazhi Pill, Kuijiening, } \\
\text { Zhenren Yangzang Decoction, } \\
\text { Wenshen Jianpi Decoction, } \\
\text { Wenyang Yuyang Decoction, } \\
\text { Fuzheng Quxie Decoction. }\end{array}$ & SASP, Mezalazine & $20 \mathrm{RCTs}$ \\
\hline 17 & $\begin{array}{l}\text { Xiong } \\
\text { AQ2011 }\end{array}$ & Decoction & $\begin{array}{l}\text { Objective evaluation of the } \\
\text { treatment of UC with TCM. }\end{array}$ & $n=582$ & $\begin{array}{l}\text { Wumei Baijiang Decoction, } \\
\text { Shaoyao Decoction, Jianpi } \\
\text { Decoction, Qingchang Yuyang } \\
\text { Decoction, Qingchang } \\
\text { Liangxue Decoction, Sijunzi } \\
\text { Decoction, Tongxieyao } \\
\text { Decoction, Jianpi Qushi } \\
\text { Huazhuo Decoction. }\end{array}$ & Mezalazine & 8 RCTs \\
\hline 18 & Lv C2014 & NR & $\begin{array}{l}\text { To evaluate the efficacy and } \\
\text { safety of clearing away } \\
\text { intestinal dampness and heat } \\
\text { methods on UC. }\end{array}$ & $n=1797$ & NR & $\begin{array}{l}\text { SASP, Mezalazine, } \\
\text { Metronidazole, Osalazina }\end{array}$ & $20 \mathrm{RCTs}$ \\
\hline 19 & $\begin{array}{l}\text { Wang } \\
\text { DY2011 }\end{array}$ & $\begin{array}{l}\text { Decoction, } \\
\text { Chinese } \\
\text { patent } \\
\text { medicine }\end{array}$ & $\begin{array}{l}\text { To evaluate heat spleen with } \\
\text { wet method in active } \\
\text { treatment the curative effect } \\
\text { of } U C \text { and security, to reveal } \\
\text { the advantages of the method } \\
\text { in active treatment of UC } \\
\text { activity for TCM treatment of } \\
\text { UC to provide the basis of } \\
\text { evidence-based medicine. }\end{array}$ & $n=2641$ & $\begin{array}{l}\text { Anchang Zhixie Decoction, } \\
\text { Shenling Baizhu Decoction, } \\
\text { Changyuning Granule, Gegen } \\
\text { Qinlian Decoction, Kuijie } \\
\text { Decoction, Lipi Yuyang } \\
\text { Decoction, Baitouweng } \\
\text { Decoction, Mankuining, } \\
\text { Qinghua Changyin }\end{array}$ & $\begin{array}{l}\text { SASP, Mezalazine, } \\
\text { Hormones, } \\
\text { Smecta,Metronidazole, } \\
\text { Gentamicin, Placebo }\end{array}$ & $36 \mathrm{RCTs}$ \\
\hline 20 & $\begin{array}{l}\text { Liu } \\
\text { TW2016 }\end{array}$ & Decoction & $\begin{array}{l}\text { To explore the effectiveness } \\
\text { and safety of Paeoniae } \\
\text { decoction in the treatment of } \\
\text { UC. }\end{array}$ & $n=1181$ & Shaoyao Decoction & $\begin{array}{l}\text { BaWei XiLei Powder, } \\
\text { SASP, Metronidazole, } \\
\text { berberine, hydrocortisone, } \\
\text { oxalazine, hormones }\end{array}$ & 17 RCTs \\
\hline 21 & $\begin{array}{l}\text { Yang } \\
\text { L2017 }\end{array}$ & Decoction & $\begin{array}{l}\text { To evaluate the efficacy of } \\
\text { Shaoyao Decoction in the } \\
\text { therapy of UC. }\end{array}$ & $n=637$ & Shaoyao Decoction & SASP, Mezalazine & 9 RCTs \\
\hline 22 & $\begin{array}{l}\text { Zhang } \\
\text { WN2017 }\end{array}$ & $\begin{array}{l}\text { Decoction, } \\
\text { Oitment }\end{array}$ & $\begin{array}{l}\text { To evaluate the efficacy of } \\
\text { Tongxie Yaofang in the }\end{array}$ & $n=696$ & $\begin{array}{l}\text { prescription for treating } \\
\text { diarrhoea with abdominal }\end{array}$ & $\begin{array}{l}\text { SASP, Probiotics, } \\
\text { Norfloxacin, Vitamin, }\end{array}$ & 8 RCTs \\
\hline
\end{tabular}


Table 2 Summary of the included systematic reviews (Continued)

\begin{tabular}{|c|c|c|c|c|c|c|c|}
\hline No. & $\begin{array}{l}\text { Study ID } \\
\text { (first } \\
\text { author, } \\
\text { year) }\end{array}$ & Interventions & $\begin{array}{l}\text { Review objectives (quote } \\
\text { from the original paper) }\end{array}$ & Population & Intervention (TCM used) & Comparator & $\begin{array}{l}\text { Number } \\
\text { of } \\
\text { studies }\end{array}$ \\
\hline & & & therapy of UC. & & $\begin{array}{l}\text { pain, Baizhu Shaoyao Powder, } \\
\text { Changyanling }\end{array}$ & Smecta & \\
\hline 23 & $\begin{array}{l}\text { Chen } \\
\text { F2012 }\end{array}$ & Decoction & $\begin{array}{l}\text { To evaluate the kidney and } \\
\text { spleen method in the } \\
\text { treatment of remission of UC } \\
\text { efficacy and safety. }\end{array}$ & $n=2928$ & $\begin{array}{l}\text { Wenyang Yiqi Jiedu } \\
\text { Decoction, Wumei Pill, Zhenpi } \\
\text { Decoction, Huangqi Jianzhong } \\
\text { Decoction, Bupi Yichang } \\
\text { Decoction, Wenshen Hezhong } \\
\text { Decoction, Fuzi Lizhong } \\
\text { Decoction, Sishen Pill, } \\
\text { Shenling Baizhu Powder, } \\
\text { Buzhong Yiqi Decoction, } \\
\text { Lizhong Decoction, Kuijieling, } \\
\text { Xileisan, Qiwei Baizhu Powder, } \\
\text { Jianpi Yishen Formula, } \\
\text { Jiechang Kang, Wenbu Zhixie } \\
\text { Decoction, Weichangning } \\
\text { Decoction, Huangtu } \\
\text { Decoction, Jianpi Lichang } \\
\text { Decoction, Tiaozhong Lichang } \\
\text { Decoction, Jiedu Shengji } \\
\text { Decoction, Lianli Decoction } \\
\text { and Zhenren Yangzang } \\
\text { Decoction }\end{array}$ & $\begin{array}{l}\text { SASP, Mezalazine, Xileisan, } \\
\text { Smecta, Norfloxacin, } \\
\text { Hormone, Gentamicin }\end{array}$ & 35 RCTs \\
\hline 24 & $\begin{array}{l}\text { Yan } \\
\text { SG2013 }\end{array}$ & Decoction & $\begin{array}{l}\text { To evaluate the efficacy of } \\
\text { Wumei Pill in the therapy of } \\
\text { UC. }\end{array}$ & $n=1170$ & Wumei Pill & $\begin{array}{l}\text { SASP, Bupi Yichang Pill, } \\
\text { Amoxicillin }\end{array}$ & 10 RCTs \\
\hline 25 & $\begin{array}{l}\text { Xiong } \\
J 2008\end{array}$ & Decoction & $\begin{array}{l}\text { To evaluate the efficacy of } \\
\text { Wumei Pill in the therapy of } \\
\text { UC. }\end{array}$ & $n=1159$ & $\begin{array}{l}\text { SASP, Wumei Pill, Zhenren } \\
\text { Yangzang Decoction, Qiwei } \\
\text { Baizhu, Liujunzi Decoction, } \\
\text { Sishen Pill }\end{array}$ & SASP, Hormone & 10 RCTs \\
\hline 26 & $\begin{array}{l}\text { Chen } \\
\text { MY2018 }\end{array}$ & $\begin{array}{l}\text { Chinese } \\
\text { patent } \\
\text { medicine }\end{array}$ & $\begin{array}{l}\text { To systematically evaluate the } \\
\text { clinical efficacy and safety of } \\
\text { Xilei Powder compared with } \\
\text { mesalamine in the treatment } \\
\text { of UC. }\end{array}$ & $n=373$ & Xilei Powder & Mezalazine & $6 \mathrm{RCTS}$ \\
\hline 27 & $\begin{array}{l}\text { Chen } \\
\text { MY2018-a }\end{array}$ & $\begin{array}{l}\text { Chinese } \\
\text { patent } \\
\text { medicine }\end{array}$ & $\begin{array}{l}\text { Meta-analysis of Xileisan } \\
\text { combined with Mesalazine in } \\
\text { the treatment of UC. }\end{array}$ & $n=840$ & Xilei Powder & SASP, Hormone & $12 \mathrm{RCTs}$ \\
\hline 28 & $\begin{array}{l}\text { Cui } \\
\text { DJ2012 }\end{array}$ & $\begin{array}{l}\text { Chinese } \\
\text { patent } \\
\text { medicine }\end{array}$ & $\begin{array}{l}\text { To evaluate the efficacy and } \\
\text { safety of Xilei powder on UC. }\end{array}$ & $n=83$ & Xilei Powder & Mezalazine & 2 RCTs \\
\hline 29 & $\begin{array}{l}\text { Ma } \\
\text { XM2012 }\end{array}$ & $\begin{array}{l}\text { Chinese } \\
\text { patent } \\
\text { medicine }\end{array}$ & $\begin{array}{l}\text { To systematically evaluate the } \\
\text { clinical efficacy of Xileisan in } \\
\text { the treatment of UC. }\end{array}$ & $n=1476$ & Xilei Powder & $\begin{array}{l}\text { SASP, 5-ASA, Smecta, Hor- } \\
\text { mone, Antibiotic }\end{array}$ & $21 \mathrm{RCTs}$ \\
\hline 30 & $\begin{array}{l}\text { Lai } \\
\text { YL2013 }\end{array}$ & Decoction & $\begin{array}{l}\text { To evaluate the clinical } \\
\text { efficacy of TCM with Xinkai } \\
\text { Kujiang method in the } \\
\text { treatment of UC. }\end{array}$ & $n=551$ & $\begin{array}{l}\text { Wumei Pill, Lianli Wumei } \\
\text { Decoction, Chaigui Ganjiang } \\
\text { Decoction }\end{array}$ & SASP, Mezalazine & 9 RCTs \\
\hline 31 & $\begin{array}{l}\text { Zhu } \\
\text { JB2016 }\end{array}$ & Decoction & $\begin{array}{l}\text { To make a systematic review } \\
\text { on the clinical effect and } \\
\text { safety of modifiedBanxia } \\
\text { Xiexin Decoction in the } \\
\text { treatment of UC. }\end{array}$ & $n=1200$ & Banxia Xiexin Decoction & NR & 14 RCTs \\
\hline 32 & $\begin{array}{l}\text { Huang } \\
\text { ZB2014 }\end{array}$ & $\begin{array}{l}\text { Chinese } \\
\text { patent } \\
\text { medicine }\end{array}$ & $\begin{array}{l}\text { To systematically evaluate the } \\
\text { effectiveness of Yunnan } \\
\text { Baiyao in treating UC. }\end{array}$ & $n=1463$ & Yunnan white Drug & SASP, 5-ASA & 20 RCTs \\
\hline 33 & Qi J2016 & Decoction & $\begin{array}{l}\text { To evaluate the clinical } \\
\text { efficacy of Zhenren Yangzang }\end{array}$ & $n=209$ & Zhenren Yangzang Decoction & SASP & 3 RCTs \\
\hline
\end{tabular}


Table 2 Summary of the included systematic reviews (Continued)

\begin{tabular}{|c|c|c|c|c|c|c|c|}
\hline No. & $\begin{array}{l}\text { Study ID } \\
\text { (first } \\
\text { author, } \\
\text { year) }\end{array}$ & Interventions & $\begin{array}{l}\text { Review objectives (quote } \\
\text { from the original paper) }\end{array}$ & Population & Intervention (TCM used) & Comparator & $\begin{array}{l}\text { Number } \\
\text { of } \\
\text { studies }\end{array}$ \\
\hline & & & UC. & & & & \\
\hline 34 & luo Y2012 & NR & $\begin{array}{l}\text { Evaluation the efficicy and } \\
\text { safety about the Chinese and } \\
\text { Western method of treatment } \\
\text { on UC. }\end{array}$ & $n=7740$ & NR & NR & 113 RCTs \\
\hline 35 & Xu P2015 & $\begin{array}{l}\text { Decoction, } \\
\text { Chinese } \\
\text { patent } \\
\text { medicine }\end{array}$ & $\begin{array}{l}1 \text { To sum up the results of the } \\
\text { RCT about the treatments of } \\
\text { UC with integrative } \\
\text { medicine. } 2 \text { Using Mete- } \\
\text { analysis methods to evaluate } \\
\text { the effectiveness, safety and } \\
\text { the rates of recurrence,in } \\
\text { order to provide reference } \\
\text { and guidance for clinical treat- } \\
\text { ment of UC. }\end{array}$ & $n=1696$ & $\begin{array}{l}\text { Pulsatilla Decoction, Kangfuxin } \\
\text { Liquid, Hongteng Decoction, } \\
\text { Puqin Baijiang Decoction }\end{array}$ & conventional medicine & 20 RCTs \\
\hline 36 & $\begin{array}{l}\text { Gong } \\
\text { YD2012 }\end{array}$ & NR & $\begin{array}{l}\text { Evaluate wether conventional } \\
\text { medicine combined TCM } \\
\text { therapy more advantageous } \\
\text { than simple Western medicine } \\
\text { therapy. }\end{array}$ & $n=1897$ & NR & conventional medicine & $16 \mathrm{RCTs}$ \\
\hline 37 & $\begin{array}{l}\text { Ma } \\
\text { DZ2015 }\end{array}$ & NR & $\begin{array}{l}\text { Comprehensive evaluation of } \\
\text { the clinical efficacy of } \\
\text { retention enema with TCM in } \\
\text { the adjuvant treatment of UC. }\end{array}$ & $n=1358$ & NR & conventional medicine & 18 RCTs \\
\hline 38 & $\begin{array}{l}\text { Huang } \\
\text { SG2010 }\end{array}$ & $\begin{array}{l}\text { Decoction, } \\
\text { Chinese } \\
\text { patent } \\
\text { medicine }\end{array}$ & $\begin{array}{l}\text { Applying the method of } \\
\text { Meta-Analysis, generally evalu- } \\
\text { ation the therapeutic effect of } \\
\text { retention-enema of Chinese } \\
\text { herb treating UC. }\end{array}$ & $n=875$ & $\begin{array}{l}\text { Danshen enema, Hongteng } \\
\text { mixture, Kuju solution, } \\
\text { Kuijieqing enema, Huangqi } \\
\text { Decoction, Baitouweng } \\
\text { Decoction }\end{array}$ & $\begin{array}{l}\text { SASP, Hormone, } \\
\text { Antibiotic, } \\
\text { Sulfamethoxazole }\end{array}$ & $7 \mathrm{RCTs}$ \\
\hline 39 & $\begin{array}{l}\mathrm{Ni} \\
X X 2019\end{array}$ & $\begin{array}{l}\text { Decoction, } \\
\text { Chinese } \\
\text { patent } \\
\text { medicine }\end{array}$ & $\begin{array}{l}\text { To systematically evaluate the } \\
\text { efficacy and safety of } \\
\text { retention enema with Chinese } \\
\text { materia in the treatment of } \\
\text { UC. }\end{array}$ & $n=3110$ & $\begin{array}{l}\text { Yunnan white Drug, Xilei } \\
\text { Powder, Qibei Mixture, } \\
\text { Zhikang Capsule, Shenling } \\
\text { Baizhu Powder }\end{array}$ & conventional medicine & 36 RCTs \\
\hline 40 & $\begin{array}{l}\text { Jiang } \\
\text { T2006 }\end{array}$ & NR & $\begin{array}{l}\text { To assess the theraoeutic } \\
\text { effectiveness of retention } \\
\text { enema with TCM in the } \\
\text { treatment of UC. }\end{array}$ & $n=2092$ & NR & $\begin{array}{l}\text { SASP, Hormone, } \\
\text { Antibiotic }\end{array}$ & $23 \mathrm{RCTs}$ \\
\hline 41 & $\begin{array}{l}\text { Zhu } \\
\text { XG2012 }\end{array}$ & $\begin{array}{l}\text { Decoction, } \\
\text { Chinese } \\
\text { patent } \\
\text { medicine }\end{array}$ & $\begin{array}{l}\text { Comprehensive evaluation of } \\
\text { clinical efficacy of retention } \\
\text { enema with TCM in the } \\
\text { treatment of UC. }\end{array}$ & $n=1584$ & $\begin{array}{l}\text { Yunnan White Drug, Jiechang } \\
\text { Decoction, Kuijiekang, Kuju } \\
\text { Liquid, Yuchang Zhengchang } \\
\text { Decoction, Tongguan } \\
\text { Decoction, Yasanzi Sanhuang } \\
\text { Decoction, Hongteng Mixture, } \\
\text { Yuyang Anchang Decoction, } \\
\text { Danshen enema Liquid, Xilei } \\
\text { Liquid, Kuijieqing enema } \\
\text { Liquid, Pulsatilla Decoction, } \\
\text { Huangqi Decoction. }\end{array}$ & $\begin{array}{l}\text { SASP, Hormone, } \\
\text { Antibiotic, Smecta, } \\
\text { Sulfamethoxazole } \\
\text { compound }\end{array}$ & $15 \mathrm{RCTs}$ \\
\hline 42 & $\begin{array}{l}\text { You } \\
\text { WF2017 }\end{array}$ & NR & $\begin{array}{l}\text { Quantitative analysis of clinical } \\
\text { efficacy of retention enema of } \\
\text { TCM for UC based on } \\
\text { evidence-based medicine } \\
\text { methodology. }\end{array}$ & $n=988$ & NR & NR & 7 RCTs \\
\hline 43 & $\begin{array}{l}\text { Cui DJ- } \\
\text { a2012 }\end{array}$ & $\begin{array}{l}\text { Chinese } \\
\text { patent } \\
\text { medicine }\end{array}$ & $\begin{array}{l}\text { To evaluate the efficacy and } \\
\text { safety of Bupi Yichang Pill in } \\
\text { the therapy of UC. }\end{array}$ & $n=596$ & Bupi Yichang Pill & $\begin{array}{l}\text { SASP, Mezalazine, } \\
\text { balsalazide }\end{array}$ & 6 RCTs \\
\hline 44 & WuZI2017 & $\begin{array}{l}\text { Decoction, } \\
\text { Chinese }\end{array}$ & $\begin{array}{l}\text { To evaluate the therapeutic } \\
\text { effect of TCM enema }\end{array}$ & $n=1521$ & $\begin{array}{l}\text { Changkui Decoction, } \\
\text { Qingchang Huashi Decoction, }\end{array}$ & Mezalazine & 22 RCTs \\
\hline
\end{tabular}


Table 2 Summary of the included systematic reviews (Continued)

\begin{tabular}{|c|c|c|c|c|c|c|c|}
\hline No. & $\begin{array}{l}\text { Study ID } \\
\text { (first } \\
\text { author, } \\
\text { year) }\end{array}$ & Interventions & $\begin{array}{l}\text { Review objectives (quote } \\
\text { from the original paper) }\end{array}$ & Population & Intervention (TCM used) & Comparator & $\begin{array}{l}\text { Number } \\
\text { of } \\
\text { studies }\end{array}$ \\
\hline & & $\begin{array}{l}\text { patent } \\
\text { medicine }\end{array}$ & $\begin{array}{l}\text { combined with mesalazine in } \\
\text { treating UC. }\end{array}$ & & $\begin{array}{l}\text { Qingchang Yuyang Decoction, } \\
\text { Shenling Baizhu Powder and } \\
\text { Baitouweng Decoction }\end{array}$ & & \\
\hline 45 & $\begin{array}{l}\text { Huang } \\
\text { HJ2012 }\end{array}$ & NR & $\begin{array}{l}\text { The objective of this study } \\
\text { was to systematicly ewduate } \\
\text { the clinical therapeutic effcct } \\
\text { of Chinese materia medica } \\
\text { and western drugs used in } \\
\text { retention enema for treating } \\
\text { UC. }\end{array}$ & $n=476$ & NR & NR & 5 RCTs \\
\hline 46 & $\begin{array}{l}\text { Zha } \\
\text { AS2015 }\end{array}$ & NR & $\begin{array}{l}\text { The aim of this study was to } \\
\text { evaluate the safety and } \\
\text { efficacy of Huoxue } \\
\text { Huayumethod of TCM in the } \\
\text { treatment of UC. }\end{array}$ & $n=1897$ & NR & $\begin{array}{l}\text { Mezalazine, SASP, } \\
\text { Hormones, Antibiotics, } \\
\text { Metronidazole }\end{array}$ & 20 RCTs \\
\hline 47 & $\begin{array}{l}\text { Hou } \\
\text { LW2017 }\end{array}$ & Decoction & $\begin{array}{l}\text { To review systematically the } \\
\text { therapeutic effects and safety } \\
\text { on UC treated with the oral } \\
\text { administration and enema } \\
\text { with TCM }\end{array}$ & $n=1507$ & $\begin{array}{l}\text { Tiaoqi Jiedu Decoction, } \\
\text { Yuchang Decoction, Shenling } \\
\text { Baizhu Powder, Gegen Qinlian } \\
\text { Decoction, Shaoyao } \\
\text { Decoction, Changyan } \\
\text { Decoction, Jianpi Lichang } \\
\text { Decoction, Self-made Xiaoul- } \\
\text { cer, Gegen Qinlian Wutan } \\
\text { Decoction }\end{array}$ & $\begin{array}{l}\text { SASP, Hormones, } \\
\text { Ampicillin }\end{array}$ & $18 \mathrm{RCTs}$ \\
\hline 48 & $\begin{array}{l}\text { Hou } \\
\text { LW2015 }\end{array}$ & $\begin{array}{l}\text { Decoction, } \\
\text { Chinese } \\
\text { patent } \\
\text { medicine }\end{array}$ & $\begin{array}{l}\text { To systematically evaluate } \\
\text { clinical efficacy of oral } \\
\text { medicine decoction with } \\
\text { enema treatment of UC. }\end{array}$ & $n=856$ & $\begin{array}{l}\text { Colon Ning Mixture, } \\
\text { Yuyangning Decoction, } \\
\text { Tongxie Yaofang, Shenling } \\
\text { Baizhu Powder, Shaoyao } \\
\text { Decoction, Gegen Qinlian } \\
\text { Decoction, Gegen Qinlian } \\
\text { Wutan Decoction }\end{array}$ & $\begin{array}{l}\text { SASP, Hormones, } \\
\text { Antibiotic }\end{array}$ & $11 \mathrm{RCTS}$ \\
\hline 49 & $\begin{array}{l}\text { Gan } \\
\text { YK2015 }\end{array}$ & Decoction & $\begin{array}{l}\text { To evaluate the efficacy of } \\
\text { TCM for oral compared with } \\
\text { Mesalazine in thetreatment of } \\
\text { UC through meta-analysis. }\end{array}$ & $n=543$ & $\begin{array}{l}\text { Changqingshu Decoction, } \\
\text { Sijunzi Decoction and Tongxie } \\
\text { Decoction, Qingchang Yuyang } \\
\text { Decoction, Wumei Baicai } \\
\text { Decoction, Jianpi Decoction, } \\
\text { Qingchang Liangxue } \\
\text { Decoction, Jianpi Qushihuo } \\
\text { Decoction }\end{array}$ & Mezalazine & 7 RCTs \\
\hline 50 & $\begin{array}{l}\text { Zhu } \\
\text { JM2011 }\end{array}$ & NR & $\begin{array}{l}\text { To evaluate the clinical } \\
\text { efficacy of Chinese medicine } \\
\text { treatment on UC. }\end{array}$ & $n=2702$ & NR & $\begin{array}{l}\text { SASP, Basalazide, } \\
\text { Mesalazine, Smecta, } \\
\text { Antibiotics, Hormones, } \\
\text { Vitamins }\end{array}$ & 33 RCTs \\
\hline 51 & $\begin{array}{l}\text { Wang } \\
\text { DY2013 }\end{array}$ & $\begin{array}{l}\text { Decoction, } \\
\text { Chinese } \\
\text { patent } \\
\text { medicine }\end{array}$ & $\begin{array}{l}\text { To evaluate the curative effect } \\
\text { and safety of TCM Heat- } \\
\text { Clearing and Damp-Excreting } \\
\text { and Spleen-Strengthening } \\
\text { Method for the treatment of } \\
\text { active UC. }\end{array}$ & $n=896$ & $\begin{array}{l}\text { Modified Yuyang Decoction, } \\
\text { Huangqi Jianzhong Decoction, } \\
\text { Huoxue Lichang Decoction, } \\
\text { Jianpi Lishi Decoction, } \\
\text { Kuijieling No. 1, Qibaiyichang } \\
\text { Decoction, Qini Yuyang } \\
\text { Decoction, Baitouweng } \\
\text { Decoction, Kuijiefukang } \\
\text { Decoction, Qingre Lishi } \\
\text { Yichang Decoction, } \\
\text { Baitouweng Decoction, Liuhe } \\
\text { Decoction, Jianpiyukui } \\
\text { Decoction, Chinese Herbal } \\
\text { Enema Prescription }\end{array}$ & $\begin{array}{l}\text { SASP, Smecta, Hormone, } \\
\text { Ciprofloxacin }\end{array}$ & 13 RCTs \\
\hline 52 & $\begin{array}{l}\text { Wang } \\
\text { Y2018 }\end{array}$ & NR & $\begin{array}{l}\text { To evaluate the regulation of } \\
\text { gut flora in patients with UC } \\
\text { on TCM. }\end{array}$ & $n=392$ & NR & SASP, Mezalazine & 5 RCTs \\
\hline
\end{tabular}


Table 2 Summary of the included systematic reviews (Continued)

\begin{tabular}{|c|c|c|c|c|c|c|c|}
\hline No. & $\begin{array}{l}\text { Study ID } \\
\text { (first } \\
\text { author, } \\
\text { year) }\end{array}$ & Interventions & $\begin{array}{l}\text { Review objectives (quote } \\
\text { from the original paper) }\end{array}$ & Population & Intervention (TCM used) & Comparator & $\begin{array}{l}\text { Number } \\
\text { of } \\
\text { studies }\end{array}$ \\
\hline 53 & $\begin{array}{l}\mathrm{He} \\
\text { M2007 }\end{array}$ & NR & $\begin{array}{l}\text { Comparing the clinical efficacy } \\
\text { of TCM preparation and SASP } \\
\text { in the treatment of UC. }\end{array}$ & $n=611$ & NR & SASP & $7 \mathrm{RCTS}$ \\
\hline 54 & $\begin{array}{l}\text { Pei } \\
\text { QW2013 }\end{array}$ & $\begin{array}{l}\text { Decoction, } \\
\text { Chinese } \\
\text { patent } \\
\text { medicine }\end{array}$ & $\begin{array}{l}\text { To evaluate the effectiveness } \\
\text { and safety of method of } \\
\text { chinese herbs oral therapy for } \\
\text { treating UC. }\end{array}$ & $n=1923$ & $\begin{array}{l}\text { Tongxiening Granule, Fuling } \\
\text { Powder, Wumei Pill, Mahuang } \\
\text { Fuzi Xixin Decoction, } \\
\text { Compound Kushen Colon- } \\
\text { dissolving Capsule, Xuefu } \\
\text { Zhuyu Decoction, Shaoyao } \\
\text { Decoction, Kuijie Recurrent } \\
\text { Decoction, Ulcer Powder, } \\
\text { Zhuche Pill, Guipi Decoction, } \\
\text { Changpikang, Qixian Anchang } \\
\text { Decoction, Jianpi Zaoshi De- } \\
\text { coction, Kuijietong Decoction, } \\
\text { QinGeng Chunpi Decoction Li- } \\
\text { quor, Coix Root and Fructus } \\
\text { Aconiti Patriniae Powder, } \\
\text { Changyankang Oral Liquid, } \\
\text { Warming Spleen Decoction, } \\
\text { Banxia Xiexin Decoction, } \\
\text { Danggui Shaoyao Powder, } \\
\text { Taohong Siwu Decoction, } \\
\text { Qiwei Baizhu Powder }\end{array}$ & $\begin{array}{l}\text { SASP, Hormones, } \\
\text { Oxalazine, Folic acid, } \\
\text { miya, Mesalazine }\end{array}$ & $23 \mathrm{RCTs}$ \\
\hline 55 & $\begin{array}{l}\text { Yang } \\
\text { AX2006 }\end{array}$ & NR & $\begin{array}{l}\text { To compare clinical } \\
\text { therapeutic effects of simple } \\
\text { TCM and simple conventional } \\
\text { medicines on UC. }\end{array}$ & $n=1237$ & NR & NR & $11 \mathrm{RCTs}$ \\
\hline 56 & $\begin{array}{l}\text { Zhu } \\
\text { L2012 }\end{array}$ & NR & $\begin{array}{l}\text { To compare clinical } \\
\text { therapeutic effects of simple } \\
\text { TCM and 5-ASA on UC. }\end{array}$ & $n=739$ & NR & NR & $11 \mathrm{RCTS}$ \\
\hline 57 & $\begin{array}{l}\text { Jia } \\
\text { JW2019 }\end{array}$ & $\begin{array}{l}\text { Decoction, } \\
\text { Chinese } \\
\text { patent } \\
\text { medicine }\end{array}$ & $\begin{array}{l}\text { Systematic evaluation of the } \\
\text { clinical efficacy of TCM } \\
\text { retention enema in the } \\
\text { treatment of UC. }\end{array}$ & $n=1450$ & $\begin{array}{l}\text { Colon Qingfang, Kuijie Enema } \\
\text { Decoction, Qingre Jiedu } \\
\text { Decoction, Ulcer Powder, } \\
\text { Sanqi Zicao Decoction, Diyu } \\
\text { Charcoal with Baiji, Sanhuang } \\
\text { Decoction, Kuijie Decoction, } \\
\text { Baishao Licorice Decoction }\end{array}$ & $\begin{array}{l}\text { SASP, Metronidazole, } \\
\text { Dexamethasone, } \\
\text { Hydrocortisone, } \\
\text { Mesalazine, Gentamicin, } \\
\text { Tinidazole, Gentamicin } \\
\text { sulfate, Oxalazine }\end{array}$ & 16 RCTs \\
\hline 58 & Li L2019 & Decoction & $\begin{array}{l}\text { Systematic evaluation of the } \\
\text { efficacy and safety of TCM for } \\
\text { clearing away heat and } \\
\text { dampness combined with } \\
\text { conventional medicine in the } \\
\text { treatment of UC. }\end{array}$ & $n=1176$ & $\begin{array}{l}\text { Bai Tou Weng Decoction, } \\
\text { Qingluo Huachang Decoction, } \\
\text { Gegen Qinlian Decoction, Yiqi } \\
\text { Qingchang Decoction, } \\
\text { Baitouweng plus Gancao and } \\
\text { Ejiao Decoction, Shaoyao } \\
\text { Decoction, Qingchang } \\
\text { Powder, Qingchi Powder, } \\
\text { Qingre Changyu Decoction, } \\
\text { Yu Chang Ning capsule, Kuiyu } \\
\text { Decoction }\end{array}$ & SASP, Mezalazine & $15 \mathrm{RCTs}$ \\
\hline 59 & $\begin{array}{l}\text { Chen } \\
\text { MJ2019 }\end{array}$ & $\begin{array}{l}\text { Decoction, } \\
\text { Chinese } \\
\text { patent } \\
\text { medicine }\end{array}$ & $\begin{array}{l}\text { To systematically evaluate } \\
\text { clinical effects of proprietary } \\
\text { Chinese medicine containing } \\
\text { Sophora Flavescens on UC. }\end{array}$ & $n=883$ & $\begin{array}{l}\text { Composite Sophora Colon- } \\
\text { soluble Capsules, Kuh-seng In- } \\
\text { jection, Kuh-seng enema, } \\
\text { Tongguan liquid, Baihe and } \\
\text { Kuh-seng enema, Kuh-seng } \\
\text { Huaihua mixture }\end{array}$ & SASP, Mezalazine & 9 RCTs \\
\hline 60 & $\begin{array}{l}\text { Wu } \\
\text { N2019 }\end{array}$ & Decoction & $\begin{array}{l}\text { Systematic evaluation of the } \\
\text { efficacy and safety of } \\
\text { Huangqin Decoction in UC. }\end{array}$ & $n=777$ & Huangqin Decoction & $\begin{array}{l}\text { SASP, Mezalazine, } \\
\text { Probiotics }\end{array}$ & $10 \mathrm{RCTs}$ \\
\hline 61 & $\begin{array}{l}\text { Peng } \\
\text { JF2019 }\end{array}$ & $\begin{array}{l}\text { Decoction, } \\
\text { Chinese } \\
\text { patent }\end{array}$ & $\begin{array}{l}\text { To evaluate the therapeutic } \\
\text { effect of TCM retention } \\
\text { enema in treating UC. }\end{array}$ & $n=2477$ & $\begin{array}{l}\text { Colon An Liquid, Yuanxing } \\
\text { Changan Liquid, Shengji } \\
\text { Powder, Xihuang Mixture, }\end{array}$ & SASP, Mesalazine & $28 \mathrm{RCTs}$ \\
\hline
\end{tabular}


Table 2 Summary of the included systematic reviews (Continued)

\begin{tabular}{|c|c|c|c|c|c|c|c|}
\hline No. & $\begin{array}{l}\text { Study ID } \\
\text { (first } \\
\text { author, } \\
\text { year) }\end{array}$ & Interventions & $\begin{array}{l}\text { Review objectives (quote } \\
\text { from the original paper) }\end{array}$ & Population & Intervention (TCM used) & Comparator & $\begin{array}{l}\text { Number } \\
\text { of } \\
\text { studies }\end{array}$ \\
\hline & & medicine & & & $\begin{array}{l}\text { Kuijie Powder, Huanglian } \\
\text { Decoction, Xilei Powder, } \\
\text { Kangfuxin Liquid, Pearl } \\
\text { Guchang Powder, Jiaodai } \\
\text { Decoction }\end{array}$ & & \\
\hline 62 & Fan 2019 & Decoction & $\begin{array}{l}\text { To evaluate the efficacy of } \\
\text { Gegen Qinlian Decoction for } \\
\text { UC. }\end{array}$ & $n=2028$ & $\begin{array}{l}\text { Gegen Qinlian Decoction, } \\
\text { Gegen Qinlian Wutan } \\
\text { Decoction }\end{array}$ & $\begin{array}{l}\text { Olsalazine, Sulfasalazine, } \\
\text { Methalazine, B. subtilis, } \\
\text { hydrocortisone, sodium } \\
\text { succinate }\end{array}$ & 22 RCTs \\
\hline 63 & $\begin{array}{l}\text { Chi } \\
\text { RT2019 }\end{array}$ & NR & $\begin{array}{l}\text { To evaluate the clinical } \\
\text { efficacy and safety of Shenqi } \\
\text { Baizhu Powder combined } \\
\text { with mesalazine in the } \\
\text { treatment for UC }\end{array}$ & $n=2380$ & Shenling Baizhu Powder & Methalazine & 17 RCTs \\
\hline 64 & $\begin{array}{l}\text { Tang } \\
\text { XJ2020 }\end{array}$ & NR & $\begin{array}{l}\text { To evaluate the clinical } \\
\text { efficacy of Jianpi } \\
\text { qingrehuoxue therapy for UC }\end{array}$ & $n=2374$ & $\begin{array}{l}\text { Chinese herbal medicines } \\
\text { guided by Jianpi } \\
\text { qingrehuoxue therapy }\end{array}$ & $\begin{array}{l}\text { Methalazine, SASP, live } \\
\text { binary B. subtilis }\end{array}$ & $28 \mathrm{RCTs}$ \\
\hline 65 & $\begin{array}{l}\text { Liao } \\
\text { ZW2020 }\end{array}$ & $\begin{array}{l}\text { Chinese } \\
\text { patent } \\
\text { medicine }\end{array}$ & $\begin{array}{l}\text { To assess the efficacy and } \\
\text { safety of Danshen Injection in } \\
\text { adjuvant treatment of UC }\end{array}$ & $n=1102$ & Danshen Injection & $\begin{array}{l}\text { Methalazine, SASP, live } \\
\text { binary B. subtilis }\end{array}$ & 12 RCTs \\
\hline 66 & $\begin{array}{l}\text { Long } \\
\text { TJ2020 }\end{array}$ & Decoction & $\begin{array}{l}\text { To evaluate the efficacy of } \\
\text { oral Chinese herbal } \\
\text { compound on UC } \\
\text { with damp-heat syndrome of } \\
\text { large intestine in RCTs }\end{array}$ & $n=378$ & $\begin{array}{l}\text { Gegen Qinlian decoction, } \\
\text { Yigong powder, Shaoqi } \\
\text { chunpi decoction, Qufeng } \\
\text { ningkui decoction, Hongteng } \\
\text { baijiang baitouweng } \\
\text { decoction, Baitouweng } \\
\text { decoction }\end{array}$ & Methalazine, SASP & 6 RCTs \\
\hline 67 & $\begin{array}{l}\text { Long } \\
\text { CW2021 }\end{array}$ & $\begin{array}{l}\text { Decoction, } \\
\text { Chinese } \\
\text { patent } \\
\text { medicine }\end{array}$ & $\begin{array}{l}\text { To evaluate the clinical } \\
\text { efficacy of } \\
\text { Sishen pill plus or reduce or } \\
\text { combined with retention } \\
\text { enema in the treatment of UC }\end{array}$ & $n=680$ & Sishen Pill & $\begin{array}{l}\text { Methalazine, SASP, } \\
\text { Hydrocortisone }\end{array}$ & 9 RCTs \\
\hline 68 & $\begin{array}{l}\text { Bo } \\
\text { HJ2020 }\end{array}$ & Decoction & $\begin{array}{l}\text { To evaluate the therapeutic } \\
\text { effect of Wumei pill in treating } \\
\text { UC }\end{array}$ & $n=1219$ & Wumei Pill & Methalazine, SASP & 16 RCTs \\
\hline 69 & Li PF2020 & Decoction & $\begin{array}{l}\text { To evaluate the clinical } \\
\text { efficacy and safety of Chinese } \\
\text { herbal compound enema in } \\
\text { the treatment of UC }\end{array}$ & $n=1597$ & $\begin{array}{l}\text { Baitouweng decoction, lianbei } \\
\text { mixture, Yuyang liquid, Qinjiao } \\
\text { Cangzhu decoction, Xileisan, } \\
\text { Fufang Juhua granule, } \\
\text { Changyu enema prescription, } \\
\text { Changyu enema prescription, } \\
\text { Qingre Zhixue decoction, } \\
\text { Fufang Huangbai liquid, } \\
\text { Huangqi decoction, kuijieqing, } \\
\text { Qingre Qushi decoction, } \\
\text { Sanhuang Decoction }\end{array}$ & Methalazine, SASP & 17 RCTs \\
\hline 70 & $\begin{array}{l}\text { Tan } \\
\text { GZ2020 }\end{array}$ & NR & $\begin{array}{l}\text { To evaluate the clinical } \\
\text { efficacy and safety of TCM } \\
\text { enema combined } \\
\text { with mesalazine in treating UC }\end{array}$ & $n=2272$ & NR & $N R$ & 29 RCTs \\
\hline 71 & $\begin{array}{l}\mathrm{Hu} \\
\mathrm{QH} 2021\end{array}$ & Decoction & $\begin{array}{l}\text { To analyze the clinical efficacy } \\
\text { of TCM in the treatment of } \\
\text { UC with damp-heated syn- } \\
\text { drome of large intestine in } \\
\text { using Meta. }\end{array}$ & $n=695$ & $\begin{array}{l}\text { Baitouweng decoction, Banxia } \\
\text { Xiexin decoction, } \\
\text { Changqingshu decoction, } \\
\text { Changyuning granule, Gexian } \\
\text { decoction, Jianpi Guchang } \\
\text { decoction, Jiechang decoction, } \\
\text { Qingchang Huashi decoction, } \\
\text { Kuijie decoction }\end{array}$ & Methalazine, SASP & 9 RCTs \\
\hline
\end{tabular}


Table 2 Summary of the included systematic reviews (Continued)

\begin{tabular}{|c|c|c|c|c|c|c|c|}
\hline No. & $\begin{array}{l}\text { Study ID } \\
\text { (first } \\
\text { author, } \\
\text { year) }\end{array}$ & Interventions & $\begin{array}{l}\text { Review objectives (quote } \\
\text { from the original paper) }\end{array}$ & Population & Intervention (TCM used) & Comparator & $\begin{array}{l}\text { Number } \\
\text { of } \\
\text { studies }\end{array}$ \\
\hline 72 & $\begin{array}{l}\text { Yan ZX } \\
2021\end{array}$ & Decoction & $\begin{array}{l}\text { To assess the effcacy and } \\
\text { safety of retention enema } \\
\text { with TCM for UC }\end{array}$ & $n=1392$ & $\begin{array}{l}\text { Tin-like powder, Huangkui } \\
\text { Lianchang prescription, } \\
\text { Huangkui Lianchang } \\
\text { prescription, Baishao Qiwu } \\
\text { Granules, Baitouweng and } \\
\text { Lizhong decoctions, Hongteng } \\
\text { decoction, Hongteng } \\
\text { Decoction, Hongteng } \\
\text { decoction, Buzhong Yiqi } \\
\text { Decoction, Buzhong Yiqi } \\
\text { decoction, kuijie decoction, } \\
\text { Wubeizi powder, Kuiyangning } \\
\text { decoction and some self- } \\
\text { made Chinese herbal } \\
\text { decoction }\end{array}$ & $\begin{array}{l}\text { Tin-like powder, } \\
\text { Mezalazine, SASP, 4-ASA, } \\
\text { Gentamycin, Metronida- } \\
\text { zole sodium chloride in- } \\
\text { jection, Prednisolone, } \\
\text { Dexamethasone, }\end{array}$ & 17 RCTs \\
\hline 73 & $\begin{array}{l}\text { Yuan } \\
\text { H2O2O }\end{array}$ & Decoction & $\begin{array}{l}\text { To evaluate the efficacy and } \\
\text { safety of Six Gentlemen } \\
\text { Decoction intake in the } \\
\text { treatment of UC }\end{array}$ & $n=614$ & Six Gentlemen Decoction & $\begin{array}{l}\text { Methalazine, Budesonide, } \\
\text { Spleen Yi Chang Pill }\end{array}$ & 7 RCTs \\
\hline
\end{tabular}

1. UC Ulcerative colitis 2. SASP salazosulfapyridine 3.NR not reported 4. 5-ASA 5-aminosalicylicacid 5.DAl DNA-dependent activator of IFN-regulatory factors 6. IL innammatory factors levels of interlekin 7. ESR erythrocyte sedimentation rate 8.TNF- $a$ tumor necrosis factor a 9.CRP C-reaction protein 10. IgA immunoglobulin A 11.lgM immunoglobulin M 12.lgG immunoglobulin G 


\section{Appendix 2}

Table 3 Outcomes of the included systematic reviews

\begin{tabular}{|c|c|c|}
\hline No. & $\begin{array}{l}\text { Study ID (first author, } \\
\text { year) }\end{array}$ & Outcomes (+: for positive, -: for negative) \\
\hline 1 & Gong Y2014 & Total effectiveness (+) RR $\mathbf{1 . 2 2}[\mathbf{1 . 1 5}, \mathbf{1 . 3 0}]$, Adverse reaction rate $(+)$ \\
\hline 2 & Li WH2013 & Total effectiveness (+) OR $\mathbf{5 . 5 0}[\mathbf{3 . 7 4}, \mathbf{8 . 0 8}]$, Cure rate $(+)$ OR $\mathbf{3 . 2 6}[\mathbf{2 . 4 4 , 4 . 3 5 ]}$, Adverse reaction rate $(+)$ \\
\hline 3 & Zuo HB2013 & $\begin{array}{l}\text { Total effectiveness (+) RR } \mathbf{1 . 7 5}[\mathbf{1 . 2 4}, \mathbf{2 . 4 8}] \text {, Adverse reaction rate }(+) \text {, Clinical symptoms (+), Electron enteroscopy } \\
\text { results (+) }\end{array}$ \\
\hline 4 & Pei QW2012 & 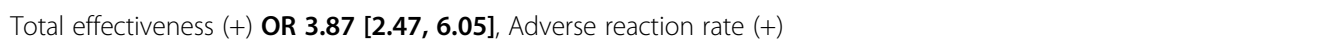 \\
\hline 5 & Wen Y2017 & Clinical effectiveness (+) RR $1.55[1.39,1.72]$, Adverse reaction rate (+), DAI (+), TNF-a (+), IL-17 (+), CRP (+) \\
\hline 6 & Chen K2016 & $\begin{array}{l}\text { Total effectiveness (+) OR } 3.30[2.25,4.82] \text {, significant effectiveness }(+) \text { OR } 2.02[1.54,2.65] \text {, inefficiency rate (+) OR } \\
0.30[0.21,0.44]\end{array}$ \\
\hline 7 & Lu2017 & Inefficiency rate $(+)$ OR $0.26[0.20,0.35]$, recurrence rate $(+)$, DAI $(+)$, TNF-a $(+)$, IL-17 (+), IL-23 (+), CRP (+) \\
\hline 8 & Wang XY2017 & $\begin{array}{l}\text { Total effectiveness }(+) \text { OR } 4.44[2.65,7.44] \text {, Cure rate }(+) \text { OR } \mathbf{1 . 7 2}[1.08,2.75] \text {, Adverse reaction rate }(+) \text {, Recurrence } \\
\text { rate }(+)\end{array}$ \\
\hline 9 & Wei Y2018 & Clinical effectiveness (+) OR $6.03[1.95,16.46]$ \\
\hline 10 & Zhang LH2018 & Total effectiveness $(+)$ OR $4.32[2.55, \mathbf{7 . 3 1}]$, Adverse reaction rate $(+)$, Recurrence rate $(+)$ \\
\hline 11 & Li HB2017 & Total effectiveness (+) OR $4.69[3.00,7.34]$, Adverse reaction rate $(-)$ \\
\hline 12 & Li HB2018 & Total effectiveness (+) OR $2.16[1.28,3.63]$, Adverse reaction rate $(-)$, TCM syndrome $(-)$, mucosal lesion $(+)$ \\
\hline 13 & Huang FMZ2014 & $\begin{array}{l}\text { Total effectiveness }(+) \text { RR } \mathbf{1 . 2 0}[\mathbf{1 . 1 5}, \mathbf{1 . 2 6}] \text {, Recurrence rate }(+), \text { DAI }(+), \operatorname{TCM} \text { syndrome }(+), \lg \mathrm{A}^{*}(+), \lg \mathrm{IM}^{*}(+), \operatorname{lgG} \mathrm{G}^{*}(+) \text {, } \\
\text { Symptom relief time }(+) \text {, stool occult blood }(+) \text {, performance of colonoscopy }(+)\end{array}$ \\
\hline 14 & Li HB-a2018 & $\begin{array}{l}\text { Total effectiveness (+) OR } 3.12[2.11,4.60] \text {, Adverse reaction rate }(+) \text {, abdominal pain }(+) \text {, diarrhea }(-) \text {, pus and blood } \\
\text { stool }(-)\end{array}$ \\
\hline 15 & Liu G2011 & Total effectiveness (+) OR $\mathbf{0 . 1 8}[\mathbf{0 . 1 1}, \mathbf{0 . 3 2}]$ \\
\hline 16 & Gu SZ2018 & Total effectiveness (+) RR $1.17[1.12,1.21]$, Adverse reaction rate $(-)$, TCM syndrome (+), DAI (+) \\
\hline 17 & Xiong AQ2011 & Clinical effectiveness (+) OR $3.71[2.26,6.10]$ \\
\hline 18 & Lv C2014 & $\begin{array}{l}\text { Total effectiveness (+) RR } 1.20[1.13, \mathbf{1 . 2 8}] \text {, Adverse reaction rate }(+) \text {, Recurrence rate }(-) \text {, IL-13 }(+) \text {, IL-8 }(-) \text {, ESR }(-) \text {, } \\
\text { CRP }(-) \text {, TCM syndrome }(+), \operatorname{lgG}(+) \text {, abdominal pain }(+) \text {, diarrhea }(+) \text {, pus and blood stool }(+) \text {, Geboes }(+) \text {, Mucosal bi- } \\
\text { opsy score }(-) \text {, performance of colonoscopy }(+) \text {, Time of bellyache disappearance }(+) \text {, Time of diarrhea disappearance } \\
(-)\end{array}$ \\
\hline
\end{tabular}

Clinical effectiveness (+) RR $1.26[1.11,1.43]$, Adverse reaction rate (+), Recurrence rate $(+)$, pus and blood stool (-), performance of colonoscopy (+)

Liu TW2016
Yang L2017
Zhang WN2017
Chen F2012
Yan SG2013
Xiong J2008
Chen MY2018
Chen MY2018-a
Cui DJ2012
Ma XM2012
Lai YL2013
Zhu JB2016
Huang ZB2014
Qi J2016
luo Y2012
Xu P2015

Total effectiveness (+) RR $\mathbf{1 . 2 0}[\mathbf{1 . 1 4}, \mathbf{1 . 2 7}]$, Adverse reaction rate (-)

Clinical effectiveness (+) RR 1.31 [1.19, 1.44], IL-6 (+), IL-8 (+), performance of colonoscopy (+), TCM syndrome (+),

Total effectiveness (+) RR $1.23[1.15,1.32]$

Clinical effectiveness (+) RR 1.27 [1.21, 1.34], Recurrence rate (+), performance of colonoscopy (+)

Total effectiveness (+) OR $4.18[2.95,5.91]$, cure rate $(+)$ OR $2.86[2.17,3.76]$, Recurrence rate $(+)$

Clinical effectiveness (+) OR $4.19[2.89,6.07]$, cure rate (+) OR $3.12[2.34,4.15]$, Recurrence rate $(+)$

Total effectiveness (-) RR 0.99 [0.91, 1.08], Adverse reaction rate (+), DAI (-), performance of colonoscopy (+)

Total effectiveness $(+)$ RR $\mathbf{1 . 2 0}[\mathbf{1 . 1 3}, \mathbf{1 . 2 6}]$, Adverse reaction rate $(-)$, Recurrence rate $(+)$, performance of colonoscopy $(+)$, Time of bellyache disappearance $(+)$, Time of diarrhea disappearance $(-)$, Time of hematochezia disappearance $(+)$

Clinical effectiveness (-) RR 0.97 [0.70, 1.35], Adverse reaction rate (-),

Total effectiveness (+) OR $5.29[3.67,7.63]$, cure rate $(+)$ OR $3.65[2.61,5.12]$, Adverse reaction rate $(+)$, DAI (+), performance of colonoscopy $(+)$, abdominal pain $(+)$, diarrhea $(+)$, pus and blood stool $(+)$

Total effectiveness (+) RR 1.14 [1.06, 1.23], cure rate (+) RR 1.54 [1.18, 2.00], Adverse reaction rate (+)

Total effectiveness (+) OR $5.20[2.63,10.29]$

Total effectiveness (+) OR $4.05[2.98,5.50]$, cure rate (+) OR $3.24[2.57,4.09]$, Adverse reaction rate (+)

Total effectiveness (+) OR $4.97[1.73,14.33]$, cure rate $(+)$ OR $3.51[1.92,6.42]$

Total effectiveness $(+)$

Total effectiveness (+) OR $4.28[3.16,5.79]$, Adverse reaction rate (+), DAI (+), IL-6 (-), performance of colonoscopy $(+)$, Time of bellyache disappearance $(+)$, Time of diarrhea disappearance $(+)$, Time of hematochezia disappearance $(+)$, 
Table 3 Outcomes of the included systematic reviews (Continued)

\begin{tabular}{|c|c|c|}
\hline No. & $\begin{array}{l}\text { Study ID (first author, } \\
\text { year) }\end{array}$ & Outcomes (+: for positive, -: for negative) \\
\hline & & Time of fever disappearance $(+)$ \\
\hline 36 & Gong YD2012 & $\begin{array}{l}\text { Clinical effectiveness (+) OR } 4.54[3.29,6.18] \text {, DAl }(+) \text {, ESR }(+) \text {, performance of colonoscopy }(+) \text {, IgA }(-) \text {, IgM }(+) \text {, IgG } \\
(-) \text {, Whole blood viscosity score }(-) \text {, plasma viscosity }(+) \text {, abdominal pain }(+) \text {, diarrhea }(+) \text {, pus and blood stool }(+) \text {, } \\
\text { tenesmus }(+)\end{array}$ \\
\hline 37 & Ma DZ2015 & Clinical effectiveness (+) OR $4.2[2.72,6.49]$ \\
\hline 38 & Huang SG2010 & Clinical effectiveness (+) OR $6.67[4.22,10.53]$ \\
\hline 39 & Ni XX2019 & $\begin{array}{l}\text { Total effectiveness }(+) \text { RR } 1.20[1.15, \mathbf{1 . 2 5}] \text {, Adverse reaction rate }(+) \text {, Recurrence rate }(+) \text {, performance of colonoscopy } \\
(+) \text {, TCM syndrome }(+)\end{array}$ \\
\hline 40 & Jiang T2006 & Clinical effectiveness $(+)$, Total effectiveness $(+)$ OR $0.24[0.14,0.39]$, Adverse reaction rate $(+)$ \\
\hline 41 & Zhu XG2012 & Total effectiveness (+) OR $6.10[4.33,8.60]$ \\
\hline 42 & You WF2017 & Clinical effectiveness (+) OR $6.34[3.97,10.14]$ \\
\hline 43 & Cui DJ-a2012 & Total effectiveness (+) RR $\mathbf{1 . 1 6}[\mathbf{1 . 0 7}, \mathbf{1 . 2 5}]$, Adverse reaction rate $(+)$, Recurrence rate $(+)$ \\
\hline 44 & Wu ZI2017 & Total effectiveness (+) RR $\mathbf{1 . 2 5}[\mathbf{1 . 1 9}, \mathbf{1 . 3 1}]$, Adverse reaction rate $(+)$, Recurrence rate $(+)$, ESR $(+)$ \\
\hline 45 & Huang HJ2012 & Total effectiveness $(+)$ OR $13.36[4.90,36.46]$, Cure rate $(+)$ OR $4.55[2.90,7.14]$ \\
\hline 46 & Zha AS2015 & Total effectiveness (+) RR $\mathbf{1 . 2 4 8}[\mathbf{1 . 1 8 7 ,} \mathbf{1 . 3 1 3 ]}$, Adverse reaction rate $(+)$ \\
\hline 47 & Hou LW2017 & $\begin{array}{l}\text { Clinical effectiveness }(+) \text {, Total effectiveness }(+) \text { RR } \mathbf{1 . 2 4}[\mathbf{1 . 1 8}, \mathbf{1 . 3 0}] \text {, Adverse reaction rate }(+) \text {, Recurrence rate }(+) \text {, } \\
\text { performance of colonoscopy }(+)\end{array}$ \\
\hline 48 & Hou LW2015 & $\begin{array}{l}\text { Clinical effectiveness }(+) \text {, Total effectiveness }(+) \text { RR } 1.32[1.23,1.41] \text {, Cure rate }(+) \text { RR } 1.91[1.35,2.70] \text {, Adverse } \\
\text { reaction rate }(+) \text {, Recurrence rate }(+) \text {, performance of colonoscopy }(+) \text {, TCM syndrome }(+)\end{array}$ \\
\hline 49 & Gan YK2015 & Clinical effectiveness (+) OR $3.36[1.96,5.76]$ \\
\hline 50 & Zhu JM2011 & Clinical effectiveness (+) RR $\mathbf{1 . 1 3}[\mathbf{1 . 0 4}, \mathbf{1 . 2 3}]$, performance of colonoscopy $(-)$, TCM syndrome $(+)$ \\
\hline 51 & Wang DY2013 & $\begin{array}{l}\text { Clinical effectiveness (+) OR } 5.16[3.35,7.95] \text {, Cure rate }(+) \text { OR } 2.9[2.10,3.98] \text {, Adverse reaction rate }(+) \text {, Recurrence } \\
\text { rate }(+)\end{array}$ \\
\hline 52 & Wang Y2018 & Bifidobacterium level $(+)$, Lactobacillus level (+), Enterococcus level (+), E. coli level (+) \\
\hline 53 & He M2007 & Clinical effectiveness (+), Total effectiveness $(+)$ OR $0.26[0.16,0.42]$ \\
\hline 54 & Pei QW2013 & $\begin{array}{l}\text { Total effectiveness }(+) \text { OR } \mathbf{5 . 0 6}[\mathbf{3 . 4 1}, \mathbf{7 . 5 2}] \text {, Adverse reaction rate }(+) \text {, performance of colonoscopy }(+), \text { TCM syndrome } \\
(+)\end{array}$ \\
\hline 55 & Yang AX2006 & Clinical effectiveness (+), Total effectiveness (+) OR $6.60[4.60,9.47]$ \\
\hline 56 & Zhu L2012 & Clinical effectiveness (+) RR $1.17[1.10,1.25]$ \\
\hline 57 & Jia JW2019 & Total effectiveness (+) OR $4.99[3.48,7.14]$, IL-6 (+), IL-10 (+), CRP (+), Mucosal biopsy score (+) \\
\hline 58 & Li L2019 & Adverse reaction rate $(+)$, Clinical efficacy $(+)$ RR $4.93[3.35,7.26]$ \\
\hline 59 & Chen MJ2019 & Total effectiveness $(+)$ OR $\mathbf{0 . 1 3}[\mathbf{0 . 0 8}, \mathbf{0 . 1 8}]$, Adverse reaction rate $(+)$ \\
\hline 60 & Wu N2019 & Total effectiveness (+) RR $1.23[1.14,1.31]$,Adverse reaction rate $(+), \operatorname{IL}-6(+)$, TNF-a $(+), \operatorname{lgA}(+), \lg G(+)$ \\
\hline 61 & Peng JF2019 & Total effectiveness $(+)$ RR $\mathbf{1 . 1 7}[\mathbf{1} .13, \mathbf{1 . 2 1}]$, Recurrence rate $(+)$, Adverse reaction rate $(+)$ \\
\hline 62 & Fan 2019 & $\begin{array}{l}\text { Total effectiveness (+) RR } 1.21[1.12,1.31] \text {, Recurrence rate }(+) \text {, Adverse reaction rate }(+), \text { performance of colonoscopy } \\
(+)\end{array}$ \\
\hline 63 & Chi RT2019 & $\begin{array}{l}\text { Total effectiveness (+) OR } 3.35[2.45,4.60], \text { DAl (+),Adverse reaction rate }(-), \text { TCM syndrome }(+) \text {, TNF-a }(+), I L-17(+) \text {, } \\
\text { IL-23 (+), ESR }(+), \text { CRP }(+)\end{array}$ \\
\hline 64 & Tang XJ2020 & Total effectiveness (+) RR $\mathbf{1 . 1 8}[\mathbf{1 . 1 4}, \mathbf{1 . 2 3}]$ \\
\hline 65 & Liao ZW2020 & $\begin{array}{l}\text { Total effectiveness (+) RR } 1.23[1.16,1.29] \text {, Recurrence rate }(+) \text {, Adverse reaction rate }(-) \text {, TNF-a }(+) \text {, IL-6 (+), IL-8 (+), } \\
\operatorname{MPV}(+), \operatorname{PLT}(+), \mathrm{FIB}(+)\end{array}$ \\
\hline 66 & Long TJ2020 & Total effectiveness (+) OR $\mathbf{3 . 8 4}[\mathbf{2 . 0 7}, \mathbf{7 . 1 3}]$, TCM syndrome (+), Mucosal biopsy score (+) \\
\hline 67 & Long CW2021 & $\begin{array}{l}\text { Total effectiveness (+) RR } 1.19[1.07,1.31] \text {, Cure rate (+) RR } 1.72[1.44,2.06] \text {, Adverse reaction rate }(+) \text {, ESR (-), CRP } \\
(+)\end{array}$ \\
\hline 68 & Bo HJ2020 & $\begin{array}{l}\text { Total effectiveness }(+) \text { RR } \mathbf{1 . 2 4}[\mathbf{1 . 1 8}, \mathbf{1 . 3 0} \text {, Recurrence rate }(+) \text {, Adverse reaction rate }(+) \text {, Efficacy of mucosal lesions } \\
(+)\end{array}$ \\
\hline 69 & Li PF2020 & $\begin{array}{l}\text { Total effectiveness }(+) \text { RR } 1.31[1.25,1.37] \text {, Recurrence rate }(+) \text {, Mayo score }(+) \text {, Adverse reaction rate }(+) \text {, TCM } \\
\text { syndrome }(+) \text {, Mucosal biopsy score }(+)\end{array}$ \\
\hline
\end{tabular}


Table 3 Outcomes of the included systematic reviews (Continued)

\begin{tabular}{|c|c|c|}
\hline No. & $\begin{array}{l}\text { Study ID (first author, } \\
\text { year) }\end{array}$ & Outcomes (+: for positive, -: for negative) \\
\hline 70 & Tan GZ2020 & Total effectiveness (+) OR $4.90[3.75,6.41]$, Adverse reaction rate (+), Efficacy of mucosal lesions (+) \\
\hline 71 & Hu QH2021 & Clinical effectiveness (+) RR $\mathbf{1 . 2 0}[1.12,1.29]$, TCM syndrome $(+)$ \\
\hline 72 & Yan ZX 2021 & Clinical effectiveness $(+)$ OR $3.87[2.71,5.51]$, Recurrence rate $(+)$, Efficacy of mucosal lesions $(+)$ \\
\hline 73 & Yuan H2020 & Clinical effectiveness $(+)$ OR $\mathbf{0 . 2 2}[\mathbf{0 . 1 3}, \mathbf{0 . 3 9}]$, Adverse reaction rate $(+)$ \\
\hline
\end{tabular}

1.DAI DNA-dependent activator of IFN-regulatory factors 2. IL innammatory factors levels of interlekin 3. ESR erythrocyte sedimentation rate

4.CRP C-reaction protein 5. IgA immunoglobulin A 6. IgM immunoglobulin M 7. IgG immunoglobulin G 7.MPV meanplateletvolume 8.PLT platelet 9.FIB fibrinogen

\section{Abbreviations}

AGA: American gastroenterology association; AMSTAR 2: A measurement tool to assess systematic reviews 2; BSG: British society of gastroenterology; CSGE: Chinese Society of gastroenterology; CD: Crohn's disease; CRP: Creaction protein; DAI: DNA-dependent activator of IFN-regulatory factors; ESR: Erythrocyte sedimentation rate; IBD: Inflammatory bowel disease; IgA: Immunoglobulin A; IgM: Immunoglobulin M; IgG: Immunoglobulin G; IL: Inflammatory factors levels of interleukin; PICOS: Participants, intervention, control, outcome, study design; SRs: Systematic reviews; TCM: Traditional Chinese medicine; UC: Ulcerative colitis; UC-CRC: UC-related colorectal cancer

\section{Supplementary Information}

The online version contains supplementary material available at https://doi. org/10.1186/s12906-021-03387-y.

Additional file 1.

\section{Acknowledgements}

We gratefully acknowledge Jodi Sellick for assisting with language edit for this manuscript.

\section{Authors' contributions}

YXS conceived the article, drafted the research protocol, retrieved the literature, analyzed the data and wrote this manuscript. XW (from Center for Evidence-based Chinese medicine) and JG screened studies and evaluated methodological quality. WBH and XW (from Center for Studies in Constitution Research of TCM) extracted data and gave suggestions for the discussion. JPL gave suggestions on the structure of the article. $X L$ provided data analysis and writing guidance. ZLL provided methodological guidance and gave suggestions on the conception of the article. All authors have read and approved this manuscript.

\section{Funding}

This mapping review was funded by the Project 81904052 supported by National Natural Science Foundation of China, the Fundamental Research Funds for the Central public welfare research institutes (No. ZZ13-YQ-075), the 13th Five-Year Plan for National Key R\&D Program of China (2018YFC1705401). The funding recipient ZZL provided methodological guidance for this study and made suggestions for modification. The funding recipient $X \mathrm{~L}$ provides the guidance for the data analysis methods and provides analytical guidance for the conclusion.

\section{Availability of data and materials}

All data generated or analyzed during this study are included in this published article and its supplementary information files.

\section{Declarations}

Ethics approval and consent to participate

Not applicable.

\section{Consent for publication}

Not applicable.

\section{Competing interests}

The authors declare that they have no competing interests.

\section{Author details}

${ }^{1}$ Center for Evidence-Based Chinese Medicine, Beijing University of Chinese Medicine, Beijing 100029, China. ${ }^{2}$ Center for Evidence Based Chinese Medicine, Institute of Basic Research in Clinical Medicine, China Academy of Chinese Medical Sciences, Beijing 100010, China. ${ }^{3}$ Neurology Department, China-Japan Friendship Hospital, Beijing 100029, China. ${ }^{4}$ Center for Studies in Constitution Research of Traditional Chinese Medicine, Beijing University of Chinese Medicine, Beijing 100029, China.

Received: 1 April 2020 Accepted: 9 August 2021

Published online: 13 September 2021

\section{References}

1. Ordas I, Eckmann L, Talamini M, et al. Ulcerative colitis. Lancet. 2012; 380(9853):1606-19. https://doi.org/10.1016/S0140-6736(12)60150-0.

2. Wu KC, Qian JM, Liang J, et al. Chinese consensus on diagnosis and treatment of inflammatory bowel disease. Chin J Pract Intern Med. 2018;38: 796-813.

3. Abraham C, Cho JH. Inflammatory bowel disease. N Engl J Med. 2009; 361(21):2066-78. https://doi.org/10.1056/NEJMra0804647.

4. Wilks S. Morbid appearances in the intestine of Miss Bankes. London Medical Gazette. 1859;2:264-5.

5. Wilks S, Moxon W. Lectures on Pathological Anatomy. Second edition. The Boston Medical and Surgical Journal. 1875. p. 133-4.

6. Adams SM, Bornemann PH. Ulcerative colitis. Am Fam Physician. 2013; 87(10):699-705.

7. Feuerstein JD, Cheifetz AS. Ulcerative colitis: epidemiology, diagnosis, and management. Mayo Clin Proc. 2014;89(11):1553-63. https://doi.org/10.1016/j. mayocp.2014.07.002

8. Kaplan GG. The global burden of IBD: from 2015 to 2025. Nat Rev Gastroenterol Hepatol. 2015;12(12):720-7. https://doi.org/10.1038/nrgastro.2 015.150.

9. Ng SC. Emerging leadership lecture: inflammatory bowel disease in Asia: emergence of a "Western" disease. J Gastroenterol Hepatol. 2015;30(3):4405. https://doi.org/10.1111/jgh.12859.

10. Ng SC, Tang W, Ching JY, et al. Incidence and phenotype of inflammatory bowel disease based on results from the Asia-pacific Crohn's and colitis epidemiology study. Gastroenterology. 2013;145(1):158-65. https://doi.org/1 0.1053/j.gastro.2013.04.007

11. Liu HW, Li L, Cen QL, et al. Ulcerative colitis treated with retention-Enema of Chinese herb:An overview of systematic reviews. J Yunnan Univ Tradit Chin Med. 2018;41:44-9.

12. Shen ZF, Wu HH, Zhu L, et al. Traditional Chinese medicine for ulcerative colitis: an overview of systematic reviews based on PRIO-harms. China J Chin Mater Med. 2020;45(03):674-82.

13. Grant MJ, Booth A. A typology of reviews: an analysis of 14 review types and associated traditional Chinese medicine for ulcerative colitis: an overview of systematic reviews based on PRIO-harms methodologies. Health Inf Libr J. 2009;26(2):91-108. https://doi.org/10.1111/j.1471-1842.2009. 00848.x.

14. Haddaway NR, Bernes C, Jonsson BG, Hedlund K. The benefits of systematic mapping to evidence-based environmental management. Ambio. 2016; 45(5):613-20. https://doi.org/10.1007/s13280-016-0773-x.

15. Shea BJ, Reeves BC, Wells G, et al. AMSTAR 2: a critical appraisal tool for systematic reviews that include randomised or non-randomised studies of healthcare interventions, or both. BMJ. 2017;358:j4008. 
16. Wang DY. Been spleen method system evaluation for the treatment of active ulcerative colitis. Master's Thesis, Shandong University of Traditional Chinese Medicine, China, 2014.

17. Feng $\mathrm{C}$. The kidney and spleen method system evaluation for the treatment of remission of ulcerative colitis. Master's Thesis, Master Shandong University of Traditional Chinese Medicine, China, 2015.

18. Hou LW, Su XL, Yang GG, et al. Systematic review on the therapeutic effects and safety of ulcerative colitis treated with oral administration and enema of Chinese herbal medicine. World J Integr Tradit Conventional Med. 2017; 12(04):445-449+460.

19. Li L, Cao H. Meta-analysis on the treatment of ulcerative colitis by clearing away heat and removing dampness combined with conventional medicine. Jiangxi J Tradit Chin Med. 2019;50:32-6.

20. Liu TW, Chen XL, Zhang BP, et al. Meta-analysis about Paeoniae decoction combined with conventional medicine to treat ulcerative colitis. Chin J Integr Trad West Med Dig. 2016;24:425-430+432.

21. Wang $X Y$, Wang $W$, Zhang $X P$, et al. Meta-analysis of Shenling baizhu powder therapeutic effect and safety of ulcerative colitis. J Community Med. 2017;15:10-3.

22. Yan SG, Hui Y, Zhou YX, et al. Curative effect evaluation and meta analysis of Wumei pill in the treatment of ulcerative colitis. Chin J Basic Med Tradit Chin Med. 2013;19:296-8.

23. Zhang WN, Wen Y, Fan SY, et al. Systematic evaluation and Meta analysis of Tongxie Yaofang plus or minus combined with conventional medicine in the treatment of ulcerative colitis. Lishizhen Med Mater Med Res. 2017;28: 1527-30.

24. Chai RT, Zhang MY, Fan MY, et al. Meta-analysis of Shenling Baizhu powder and Mezalazine in the treatment of ulcerative colitis. Chin J Ethnomed Ethnopharm. 2021;30:56-63.

25. Miao ZW, Gu MJ, Yan J, et al. Efficacy and safety of Danshen injection in adjuvant treatment of ulcerative colitis: a systematic review. Chin Arch Tradit Chin Med. 2020;38(1):51-7.

26. Bo HJ, Wang W, Peng JS, et al. Efficacy and safety of Wumei pill compared with 5-aminosalicylic acid in the treatment of ulcerative colitis: a Metaanalysis. Chin J Pharmacoepidemiol. 2020;29(7):458-64.

27. Tan GZ, Qu YZ, Pei C, et al. Meta-analysis of traditional Chinese medicine enema combined with mesalazine in treatment of ulcerative colitis. Pract Clin J Integr Tradit Chin Conventional Med. 2020;20(06):1-4+7.

28. $\mathrm{Hu} \mathrm{QH}, \mathrm{CaO} \mathrm{H}$. Meta-analysis of TCM in treating ulcerative colitis with damp-heated syndrome of large intestine. J Pract Tradit Chin Intern Med. 18 [2021-08-18]. http://kns.cnki.net/kcms/detail/21.1187.R.20210204.1532.002. html.

29. Chen MY, Li HB, Chen XL, et al. Meta-analysis of Xilei powder compared with Mezalazine in treating ulcerative colitis. Liaoning J Tradit Chin Med. 2018:45:2266-70.

30. Cui DJ, Huang GM, Liu Z, et al. Xilei powder for treatment of ulcerative colitis: a systematic evaluation. Chin Gen Pract. 2012;15:3631-3.

31. Long CW, Cao H. A meta-analysis on the efficacy of sishen pills plus or minus or combined with retention enema in the treatment of ulcerative colitis compared with conventional medicine. J Pract Tradit Chin Intern Med. 1-6 [2021-08-18]. http://kns.cnki.net/kcms/detail/21.1187.R.2021011 9.1422.004.html.

32. Chen MY, Li HB, Chen XL, et al. Meta-analysis of Xilei powder combined with Mezalazine in managing ulcerative colitis. Chin Tradit Patent Med. 2018;40:2407-14.

33. Li HB, Chen MY, Chen XL, et al. Efficacy and safety of compound Kushen Colon-release capsule versus related chemical drugs in the treatment of colitis:a Meta-analysis. China Pharm. 2018;29:695-9.

34. Li HB, Chen XL, Chen MY, et al. Meta-analysis of compound Huangbo liquid combined with chemical medicine in the treatment of ulcerative colitis. China Pharm. 2017;28:4229-32

35. Gu SZ, Xue Y, Zhang YL, et al. Meta-analysis of the efficacy of oral traditional Chinese medicine in the treatment of ulcerative colitis. Chin J Integr Trad West Med Dig. 2018;26:981-6.

36. Chen K, Li F, Wang Q. Meta-analysis of the effect of Shenlingbaizhu powder combined with conventional medicine on ulcerative colitis. Chin J Clin Gastroenterol. 2016;28:244-8.

37. Gan YK. Meta-analysis and Ragularity of prescription of randomized controlled trials on ulcerative colitis by oral traditional Chinese medicine. Master's Thesis, Tianjin University of Traditional Chinese Medicine, China 2015.
38. Gong YD. Meta-analysis of traditional Chinese and Western treatment on ulcerative colitis. Master's Thesis, Jilin University, China, 2012.

39. He M, Jiang J. Meta-analysis of the efficacy of traditional Chinese Medicine preparation and sulfasalazine in the treatment of ulcerative colitis. Liaoning J Tradit Chin Med. 2007;11:1582-3.

40. Huangfu MZ. Meta analysis of JieDuXiaoYongFa in the treatment of ulcerative colitis. Master's Thesis, Shandong University of Traditional Chinese Medicine, China, 2017.

41. Huang HJ, Zhang QQ. Chinese Materia Medica and Western drugs used in retention Enema for treating ulcerative colitis: a systematic evaluation on the clinical randomized control trial. Chin J Coloproctol. 2012;32(2):34-6.

42. Huang SG. Zhang HY, Huang HP. Meta-analysis of ulcerative colitis treated with retention-enema of Chinese herb. Liaoning J Tradit Chin Med. 2010;37: 1433-5.

43. Jia ZW, Xu W. Systematic evaluation of traditional chinese medicine retention enema for ulcerative colitis. World Latest Med Information. 2019; 19:51-52+54.

44. Liu G, Li S, Fei SJ. Effect of Kangfuxin liquid in the treatment of ulcerative colitis: a Meta-analysis. Jilin Med J. 2011;32:3927-9.

45. Lu L. Systematic review of Shenling Baizhu san in the treatment of ulcerative colitis. Master's Thesis, North China University of Science and Technology, China, 2017.

46. Ma DZ, Liu HT. Meta-analysis of the efficacy of retention enema with Chinese herbs in the adjuvant treatment of ulcerative colitis. Nei Mongol J Tradit Chin Med. 2015;34:95-6.

47. Qi J, Tang YN, Zhang YF, et al. Zhenren Yangzang decoction in treatment of ulcerative colitis: a systematic review. Liaoning J Tradit Chin Med. 2016;43: 16-9.

48. Wei Y, Chu WJ. Meta-analysis of purely traditional Chinese Medicine retention enema in the treatment of ulcerative colitis. Chin J Rural Med Pharm. 2018;25:37-9.

49. Xiong AQ. Modern Chinese literature review and Meta-analysis of the Chinese medicine in the treatment. Master's Thesis. Guangzhou University of Chinese Medicine, China, 2011.

50. Zhang LH, Ren $\mathrm{CH}$, Zhang GW. Efficacy of Fuzilizhong decoction and its modified decoction in treating ulcerative colitis: a systematic review. Med Res Educ. 2018;5:23-31.

51. Xiong J, Dong WJ, Song JS, et al. Systematic evaluation of clinical randomized controlled trials on ulcerative colitis treated with Wumei pills and addition or subtraction. Jilin J Trad Chin Med. 2008;04:296-9.

52. Yang L, Tang YP, Gon YX, et al. Meta-analysis of shaoyao decotion combined with aminosalicylic acid in the treatment of ulcerative colitis. Chin J Integr Trad West Med Dig. 2017;25:168-73.

53. Zhu JB, Du JH, Guan JZ, et al. Meta-analysis on random-control experiment of treatment of ulcerative colitis with Banxia Xiexin decoction and its decomposed recipe. J Liaoning Univ Tradit Chin Med. 2016;18:104-8.

54. Yang $A X$, Jiang W. Meta-analysis on clinical therapeutic effects of TCM in ulcerative colitis. J Tradit Chin Med. 2006;4:283-4.

55. You WF, Zhou $L$, Jin $Y$, et al. Meta-analysis of clinical efficacy of retention enema with Chinese herbs in the treatment of ulcerative colitis. Yunnan J Tradit Chin Med Mater Med. 2017;38(04):96-8.

56. Long TJ, Tang ZJ. A systematic evaluation of the efficacy of oral Chinese herbal compound on ulcerative colitis with the damp-heat syndrome of large intestine. China Med Pharm. 2020;10(9):20-23+68.

57. Yan ZX, Liu YM, Ma T, et al. Efficacy and safety of retention enema with traditional Chinese medicine for ulcerative colitis: a meta-analysis of randomized controlled trials. Complement Ther Clin Pract. 2021;42:101278. https://doi.org/10.1016/j.ctcp.2020.101278.

58. Cui DJ, Huang $B, A \cap B Q$, et al. Adjuvant therapy of ulcerative colitis with Bupi Yichang pill: a meta-analysis. World Chin J Digestol. 2012;20(28):273741. https://doi.org/10.11569/wcjd.v20.i28.2737.

59. Li WH, Hao YR. Meta-analysis of Baitouweng decoction in the treatment of ulcerative colitis. Med Inf. 2013:464-4.

60. Luo $Y$. The systematic review about the treatment of ulcerative colitis with Chinese and conventional medicine. Master's Thesis. Hubei University of Traditional Chinese Medicine, China, 2012.

61. Zhu L, Shen H. Meta-analysis on clinical therapeutic effects of TCM on ulcerative colitis. Liaoning J Tradit Chin Med. 2012;39:1297-8.

62. Gong Y. Correlation Between Pulmonary function and Th17/Treg in Ulcerative Colitis Patients and Meta-analysis of Sishen Pill for UC. PhD Thesis, Beijing University of Chinese medicine, China, 2014. 
63. Hou LW. Systematic review of the clinical effect of Oral Chinese medicine combined with Enema in the treatment of ulcerative colitis. Master's Thesis, Liaoning University of Traditional Chinese Medicine, China, 2015.

64. Jiang T, Xia B, Li C, et al. Effects of retention Enema with traditional Chinese medicines in the treatment of ulcerative colitis: a systematic appraisal. Herald Med. 2006:1016-9.

65. LV C. Systematic evaluation on treatment of ulcerative colitis by clearing the intestine and removing dampness. Master's Thesis, Chengdu University of Traditional Chinese Medicine, China, 2014

66. Ma XM, Gao HL, Yao P. Efficacy of Xileisan in patients with ulcerative colitis: a systematic review. World Chin J Digestol. 2012;20(31):3057-64. https://doi. org/10.11569/wcjd.v20.i31.3057.

67. Wang DY, Liu DM, Song T, et al. Systematic review on heat-clearing and damp-excreting and spleen-strengthening method for treatment of active ulcerative colitis. Liaoning J Tradit Chin Med. 2013;40:2525-8.

68. Zuo HB. Meta-analysis of pulsatilla decoction in the treatment of ulcerative colitis. Master's Thesis, Chengdu University of Traditional Chinese Medicine, China, 2013.

69. Zhu JM. A systematic review of clearing away damp-heat therapy on ulcerative colitis. Master's Thesis, Nanjing University of Chinese Medicine, China, 2011

70. Xu P. Integrative medicine in treating ulcerative colitis: a Meta-analysis update. Master's Thesis. Hubei University of Chinese Medicine, China, 2015.

71. Wang $Y$, Zha AS. Meta-analysis of intestinal microflora in patients with ulcerative colitis regulated by traditional. Chin Med China Health Care Nutr. 2018;28:244-5.

72. Wu ZL, Zhang SR, Wang $L$, et al. A systematic review of traditional Chinese medicine Enema combined with Mesalazine in treating ulcerative colitis Guiding J Tradit Chin Med Pharm. 2017;23:90-4.

73. Peng JF, Wang W, Peng JS, et al. Meta-analysis of therapeutic effect of retention enema with traditional Chinese medicine on ulcerative colitis. China J Chin Mater Med. 2019;44(19):4263-71. https://doi.org/10.19540/j. cnki.cjcmm.20190827.501.

74. Fan YL, Yi W, Huang H, et al. Efficacy of herbal medicine (Gegen Qinlian decoction) on ulcerative colitis a systematic review of randomized controlled trials. Medicine. 2019;98(52):e18512. https://doi.org/10.1097/MD. 0000000000018512.

75. Tang XJ, Zhang T, Fang JS, et al. Systematic review of Jianpiqingrehuoxue therapy for ulcerative colitis based on spleen deficiency and dampness stasis. Chin J Integr Trad West Med Dig. 2020;28(2):137-42.

76. Yuan H, Zhang T, Huang SK, et al. Six gentlemen decoction adding Aucklandia and Amomum (Xiangsha Liujunzi Tang) for the treatment of ulcerative colitis: a systematic review and meta-analysis of randomized clinical trials. Eur J Integr Med. 2020;36:101119. https://doi.org/10.1016/j. eujim.2020.101119.

77. Ni XX, Wang QF, Liu XL, et al. Efficacy of retention enema with Chinese meteria medica in the treatment of ulcerative colitis: a meta analysis. Pharm Care Res. 2019;19:52-8.

78. Zhu XG, Zhou T, Chen J. Systematic evaluation of the therapeutic effect of retention enema with traditional Chinese medicine on ulcerative colitis. Chin J Integr Trad West Med Dig. 2012;20:35-7.

79. Li PF, Luo Y, Zhang YL, et al. Meta-analysis of clinical efficacy of Chinese herbal compound enema in the treatment of ulcerative colitis. Tianjin J Tradit Chin Med. 2020;37(12):1390-6.

80. Zha AS, Wang Y, ZHA RY. Safety and efficacy of Huoxue Huayu method of Chinese herbal medicine for treatment of ulcerative colitis. Chin J Exp Tradit Med Formulae. 2015;21:220-4.

81. Li HB, Chen XL, Chen MY, et al. Meta-analysis of Kangfuxin liquid versus Aminosalicylic acid in treating ulcerative colitis. Liaoning J Tradit Chin Med. 2018;45:1353-6.

82. Pei QW, Sun ZC, Song XL, et al. Efficacy of Jiajian Banxia Xiexin decoction for ulcerative colitis: a systematic review. Chin J Exp Tradit Med Formulae. 2012;18:290-4

83. Huang ZB, Li XJ, Yao P, et al. Effect of Yunnan Baiyao in treating ulcerative colitis: a meta analysis. Chin J Integr Trad West Med Dig. 2014;22:199-203.

84. Wen $Y$, Weng XT, Hu Y, et al. Systematic evaluation and meta analysis of shenling baizhu powder combined with conventional medicine in the treatment of ulcerative colitis. J Guangzhou Univ Tradit Chin Med. 2017;34: 274-81.
85. Chen MJ, Ding YX, Tong ZQ. Meta-analysis of the efficacy and safety of proprietary Chinese medicine containing Kushen (Sophora Flavescens) on ulcerative colitis. Guid J Tradit Chin Med Pharm. 2019;25:81-9.

86. Wu N, Mao XK, Wan ZP, et al. Bioinformatics analysis and systematic evaluation of key genes and therapeutic Traditional Chinese Medicine of ulcerative colitis active stage. China J Chin Mater Med. 2020;45(11):2677-86.

87. Lai $Y L, L i Y, A n$ J, et al. Systematic evaluation of the clinical efficacy and safety of xinkai kujiang method in the treatment of ulcerative colitis. World J Integr Tradit conventional Med. 2013;8:757-60.

88. Pei QW, Han T, Song XL. Systematic evaluation of randomized controlled trials of oral treatment of ulcerative colitis with traditional. Chin Med Pharmacol Clin Chin Mater Med. 2013;29:157-60.

89. Wei PR, Bai Y, Wang JD. Advances in Canceration monitoring of ulcerative colitis. Modern Digestion Interv. 2018;23:127-31.

90. Haug U, Engel S, Verheyen F, et al. Estimating colorectal cancer treatment costs: a pragmatic approach exemplified by health insurance data from Germany. PLoS One. 2014;9(2):e88407. https://doi.org/10.1371/journal.pone. 0088407.

91. Jansman FG, Postma MJ, Brouwers JR. Cost considerations in the treatment of colorectal cancer. Pharmacoeconomics. 2007;25(7):537-62. https://doi. org/10.2165/00019053-200725070-00002.

92. Luo Z, Bradley CJ, Dahman BA, et al. Colon cancer treatment costs for Medicare and dually eligible beneficiaries. Health Care Financ Rev. 2010; 31(1):35-50.

93. Asher K, B SD. Ulcerative colitis practice guidelines in adults (update): American College of Gastroenterology, practice parameters committee. Am J Gastroenterol. 2004;99(7).

94. Carter MJ, Lobo AJ, Travis SPL. Guidelines for the management of inflammatory bowel disease in adults. Gut. 2004;53(Suppl 5):V1-16.

95. Bernstein DCN, Fried PM, Krabshuis DJH, et al. World gastroenterology organization practice guidelines for the diagnosis and management of IBD in 2010. Inflamm Bowel Dis. 2010;16(1):112-24. https://doi.org/10.1002/ ibd. 21048 .

96. Ouyang Q, Hu PJ, Qian JM, et al. Consensus opinions on the diagnostic and treatment specifications for inflammatory bowel disease in China. Chin J Gastroenterol. 2007:8:488-95.

97. Chen ZS, Wang XY. Consensus on the diagnosis and treatment of integrated and conventional medicine for ulcerative colitis. Chin J Integr Tradit Conventional Med Digestion. 2010;18:416-9.

\section{Publisher's Note}

Springer Nature remains neutral with regard to jurisdictional claims in published maps and institutional affiliations.

Ready to submit your research? Choose BMC and benefit from:

- fast, convenient online submission

- thorough peer review by experienced researchers in your field

- rapid publication on acceptance

- support for research data, including large and complex data types

- gold Open Access which fosters wider collaboration and increased citations

- maximum visibility for your research: over $100 \mathrm{M}$ website views per year

At BMC, research is always in progress.

Learn more biomedcentral.com/submissions 